\title{
Efficacy of Dietary and Supplementation Interventions for Individuals with Type 2 Diabetes
}

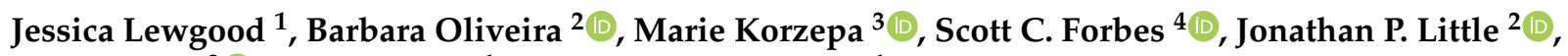 \\ Leigh Breen $^{3}\left(\mathbb{D}\right.$, Robert Bailie $^{1}$ and Darren G. Candow ${ }^{1, *}$ \\ 1 Faculty of Kinesiology and Health Studies, University of Regina, Regina, SK S4S0A2, Canada; \\ jessicalewgood@gmail.com (J.L.); Robert.Bailie@uregina.ca (R.B.) \\ 2 Okanagan Campus, School of Health and Exercise Sciences, University of British Columbia, \\ Kelowna, BC V1V1V7, Canada; barbara.oliveira@ubc.ca (B.O.); jonathan.little@ubc.ca (J.P.L.) \\ 3 School of Sport, Exercise and Rehabilitation Sciences, University of Birmingham, Edgbaston, \\ Birmingham B15 2TT, UK; MXK098@student.bham.ac.uk (M.K.); L.Breen@bham.ac.uk (L.B.) \\ 4 Department of Physical Education Studies, Faculty of Education, Brandon University, \\ Brandon, MB R7A6A9, Canada; ForbesS@BrandonU.CA \\ * Correspondence: Darren.Candow@uregina.ca; Tel.: +1-306-585-4906
}

Citation: Lewgood, J.; Oliveira, B.; Korzepa, M.; Forbes, S.C.; Little, J.P.; Breen, L.; Bailie, R.; Candow, D.G. Efficacy of Dietary and Supplementation Interventions for Individuals with Type 2 Diabetes. Nutrients 2021, 13, 2378. https: / / doi.org/10.3390/nu13072378

Academic Editor: Antonio Brunetti

Received: 7 June 2021

Accepted: 8 July 2021

Published: 12 July 2021

Publisher's Note: MDPI stays neutral with regard to jurisdictional claims in published maps and institutional affiliations.

Copyright: (C) 2021 by the authors. Licensee MDPI, Basel, Switzerland. This article is an open access article distributed under the terms and conditions of the Creative Commons Attribution (CC BY) license (https:// creativecommons.org/licenses/by/ $4.0 /)$.

\begin{abstract}
The prevalence of Type 2 diabetes (T2D) is increasing, which creates a large economic burden. Diet is a critical factor in the treatment and management of T2D; however, there are a large number of dietary approaches and a general lack of consensus regarding the efficacy of each. Therefore, the purpose of this narrative review is twofold: (1) to critically evaluate the effects of various dietary strategies on diabetes management and treatment, such as Mediterranean diet, plantbased diet, low-calorie and very low-calorie diets, intermittent fasting, low-carbohydrate and very low-carbohydrate diets, and low glycemic diets and (2) to examine several purported supplements, such as protein, branched-chain amino acids, creatine, and vitamin D to improve glucose control and body composition. This review can serve as a resource for those wanting to evaluate the evidence supporting the various dietary strategies and supplements that may help manage T2D.
\end{abstract}

Keywords: insulin; glucose; metabolism

\section{Introduction}

Diabetes encompasses a spectrum of disorders represented most prominently by an inability to properly regulate blood glucose due to an impaired response to utilize insulin, the hormone responsible for transporting glucose from the blood into cells [1]. It is estimated that $>170$ million people will have diabetes by the year 2030 [2], with the highest prevalence occurring in older adults ( $<65$ years of age) [3]. The vast majority of these individuals have type 2 diabetes (T2D) [4]. T2D is characterized by the impairment of insulin secreting $\beta$-cells in the pancreas as well as a blunted response to insulin [4]. Post-prandial hyperglycemia is a primary characteristic of T2D in older adults. While multifactorial, the age-related reduction in muscle mass/quality and muscle function may be contributing factors for developing T2D in older adults [5]. While some forms of diabetes are inherently genetic, T2D can be caused by factors associated with nutrition and physical inactivity [6]. It is well established that modifications to habitual dietary practices play an important role in the treatment and management of T2D; however, there are a large number of dietary approaches and general lack of consensus regarding the efficacy of each strategy, especially in older adults. Furthermore, conducting nutritional research is challenging and, when examining complete dietary changes, it is often difficult to identify cause and effect. Therefore, the purpose of this narrative review is twofold: (1) to critically evaluate the effects of various dietary strategies (i.e., Mediterranean; plant-based; low- and very-low calorie; intermittent fasting; low- and very-low carbohydrate, low-glycemic) on 
the management and treatment of diabetes, and (2) examine the efficacy and possibility of select dietary supplements (i.e., proteins, branched-chain amino acids, creatine, vitamin D) for treating T2D.

\section{Potential Dietary Strategies for Type 2 Diabetes}

\subsection{Mediterranean Diet}

Potential beneficial effects from the Mediterranean diet (MedDiet) in disease-state populations, specifically those with cardiovascular disease (CVD), was first hypothesized by Keys et al. in 1980 [7]. The MedDiet is an expression of different food cultures present in the Mediterranean region, with diverse food consumption and production patterns, in continuous evolution, representing the particular historical and environmental mosaic that is the Mediterranean [8]. UNESCO inscribed the Mediterranean diet in 2010 and again in 2013 on the list of the Intangible Cultural Heritage of Humanity, amplifying the significance of this regimen as a lifestyle intervention [9]. The diet is characterized by abundant plant foods (vegetables, legumes, nuts), cereals/whole grains (mainly unrefined), fresh fruit, olive oil as the principal source of fat, low to moderate intake of dairy products (principally cheese and yogurt), and fish and poultry consumed in low to moderate amounts, some eggs, red meat consumed in low amounts, and wine consumed in low to moderate amounts, normally with meals. This diet is low in saturated fat ( $<$ or $=7-8 \%$ of energy), with total fat ranging from $>25 \%$ to $<35 \%$ of energy throughout the region $[10,11]$.

Adherence to a MedDiet has been associated with a reduction in mortality [12], increased longevity [13] and prevention and management of T2D and Metabolic Syndrome [14]. The efficacy of a MedDiet in the management and prevention of T2D is now one of the most widely investigated dietary patterns amongst researchers in this area. A number of review articles have summarized the existing evidence regarding the efficacy of the MedDiet for improving cardiometabolic health in T2D and prediabetes [15-18]. Both observational and intervention studies tend to support benefits, particularly for people with T2D.

Associative evidence: A meta-analysis from 2018 concluded that the MedDiet appeared to be the most effective and efficacious dietary approach to improve glycemic control in people with T2D [19]. In addition, Esposito et al. [16] associated the MedDiet with lower HbA1c levels and improved cardiovascular risk factors, as compared with control diets, making it a dietary pattern suitable for the overall management of T2D [16]. A role for the MedDiet in the prevention of CVD outcomes has been extensively studied in several randomized controlled trials (RCTs) and prospective cohort studies, but recently Becerra-Tomás et al. [20] demonstrated its beneficial role in reducing risk, incidence and mortality from various CVD outcomes, specifically in individuals with diabetes [20]. Subsequently, there is associative evidence that the MedDiet provides benefits to cardiometabolic health and reduced mortality in people with T2D.

Intervention studies: Greco et al. [21] found that a 4-month moderate caloric restriction diet (1400-1600 kcal/day) in obese individuals that followed a MedDiet significantly improved body weight and body mass index (BMI), insulin, and insulin sensitivity (HOMAIR). Vitale et al. [22] analyzed 2568 participants with T2D and concluded that a MedDiet was associated with favorable cardiovascular risk factors profile, better glucose control and lower BMI. The MÉDITA trial [23], a single-center, randomized, controlled trial designed to investigate whether a MedDiet reduces the need for drug therapy in individuals with T2D, concluded that the MedDiet ameliorates the inflammatory milieu of T2D and Homeostatic Model Assessment (HOMA). The Cordioprev study [24] randomized patients with T2D to a low-fat diet $(n=130)$ or a MedDiet $(n=111)$ [25]. Results showed that the MedDiet improved post-prandial lipidemia and provided evidence of improvements in insulin resistance. The PREDIMED study [26] is the largest dietary intervention trial to assess the effects of the MedDiet on cardiovascular disease prevention. Many papers have been published from this study with the main paper concluding that an unrestricted-calorie, high-vegetable-fat MedDiet was associated with less gain in central adiposity and improved 
fasting glucose in participants with T2D along with decreased insulin resistance in those without diabetes.

Other studies such as The PREDIMED-Plus trial [27,28] and the Dietary Intervention Randomized Controlled Trial group (DIRECT) in Israel [29] used a MedDiet as the dietary intervention, but in an energy restricted context. The PREDIMED-Plus trial was a 6-year parallel-group, multicenter RCT involving 6874 participants recruited in 23 Spanish recruiting centers. The trial revealed improvements in glycemic control, insulin sensitivity, and dyslipidemia in individuals with or at risk for diabetes. In the Israeli study, 322 participants with moderate obesity were randomized for 2 years to one of three diet groups: low-fat, MedDiet or low-carbohydrate. Differential effects were observed in the sub-group of patients with T2D at 24 months: participants randomized to the MedDiet, which had the highest intake of dietary fibers and unsaturated to saturated fat ratio, achieved significantly greater improvements in fasting plasma glucose and insulin levels. Furthermore, special features (via dietary polyphenols and dietary fibers provided by key components of the MedDiet such as olive oil, nuts, red wine, legumes, fruits, and vegetables) have apparent additional favorable effects for patients with T2D such as reduced fasting plasma glucose and lower HbA1c levels [30].

Collectively, research findings indicate that MedDiet has positive effects on several outcome measures associated with metabolic health [31], is a viable dietary strategy for the management of T2D [16] and may reduce the risk of pre-mature mortality for individuals with T2D [32]. Moving forward, research studies should determine which components of the MedDiet generate specific health benefits. For example, are the metabolic and health benefits related to specific components of a MedDiet (e.g., olive oil, nuts)? Are these purported benefits the result of a shift from a highly processed "Western"-style diet to an unprocessed MedDiet? Or could the benefits be the results of better adherence to the MedDiet?

\subsection{Plant-Based Diets}

Plant-based diets aim to maximize consumption of nutrient-dense plant foods while minimizing processed foods, oils, and animal foods (including dairy products and eggs). In general, these diets emphasize vegetables, fruits, beans, peas, lentils, soybeans, seeds, and nuts. There is evidence that a broadly defined plant-based diet can have significant health benefits [33]. It should be noted that the term "plant-based" is sometimes used interchangeably with vegetarian or vegan. Among these approaches, macronutrient intakes are commonly distributed as $35-40 \%$ fat, $16-17 \%$ protein and $40-50 \%$ carbohydrates, with a high ingestion of fibers (15-20 g/day) [34]. As with all types of diets, vegetarian or vegan diets adopted for ethical, religious, or other reasons may or may not be healthy [35].

Plant-based diets have received increasing interest for their use in the management of T2D. Diabetes Canada endorses plant-based diets for the management of T2D because of their potential to have favorable effects on body weight, $\mathrm{HbA1c}$, LDL-cholesterol, total cholesterol and non-HDL-cholesterol levels [36]. However, it is important to note that refined grains, starches, and sugars can also be characterized as plant-based, although they are independently associated with a higher risk for developing T2D [37]. Hence, the effects of plant-based diets on the prevention and treatment of T2D are not universal and requires further research [38].

Associative evidence: Vegetarian diets are often associated with weight loss, as is the case with most calorie deficit diets [34,39,40], making it difficult to assume that any improvement in glycemic control is related to the plant-based diet per se. A meta-analysis comparing different dietary approaches, including the vegetarian diet, did not conclude its superiority over diets such as MedDiet, low-carbohydrate or Paleolithic in weight loss or various glycemic parameters [19]. However, diets with higher ingestion of plant-based foods and reduced intake of animal-based foods have been associated with lower risk for cardiovascular morbidity and mortality [41-43]. The American Heart Association, American Diabetes Association (ADA) and the European Association for the Study of 
Diabetes (EASD) recognize the benefits of eating a plant-based diet as long as food choices are nutritious [44,45]. A recent systematic review suggested that a shift to a plant-based diet may lead to favorable effects on glycemic control in individuals diagnosed with T2D [46]. Similar findings were obtained by Qian et al. supporting the health benefits of increased plant-based food consumption in lowering the risk of T2D and other cardiometabolic diseases [38].

Intervention studies: Body weight, $\mathrm{HbA} 1 \mathrm{c}$ and cardiovascular benefits of plant-based diets became popularized in 2006 after the study by Barnard et al. [39]. More recently, the BROAD study [47] compared standard medical care (control) to standard medical care plus a diet change program (intervention) of a low-fat, plant-based diet. The intervention led to significant and sustained reductions in body mass index (BMI: $-3.9 \mathrm{~kg} / \mathrm{m}^{2}$ ), body weight and cholesterol $(-0.45 \mathrm{mmol} / \mathrm{L})$ compared with the control group. Several other trials in participants with T2D also report weight loss and improvements in markers of insulin resistance following plant-based dietary interventions [34,40,41].

Plant-based diets improve weight status and increase dietary fiber but limit heme iron and vitamin B12 ingestion [48]. Thus, assistance in meal planning to minimize risk of nutrient deficiencies, maximize glycemic control, and address individual dietary preferences is recommended. Overall, the impact of plant-based diets (broadly defined) on the prevention and management of T2D and its complications show some promise, but still requires further investigation.

\subsection{Low-Calorie Diets}

Low-calorie diets (LCD), also referred to as low-energy diets, hypocaloric diets, or calorie restriction diets, have a scientific record for treating obesity-related conditions dating back to the late 1920s, where the 300 to $400 \mathrm{kcal} /$ day diet of Strang et al. produced average weight losses of $9.9 \mathrm{~kg}$ in 8 weeks in a large series of patients [49].

Calorie restriction is the only known strategy to robustly improve health and lifespan in most, if not all, living organisms [50]. It leads to numerous changes in animal models, including alterations in body composition, energy expenditure, oxidative stress/damage, cardiovascular disease, insulin sensitivity, neuroendocrine function, and gene expression [51]. Studies involving fasting have progressed to different clinical procedures, including dietary protein or protein and carbohydrates with fasting, to preserve lean body mass [52]. This strategy led to recent definitions of very low-calorie diets or calorie restriction diets as dietary regimens low in calories without undernutrition [53].

LCDs are defined as providing 1200-1500 kcal/day whereas very low-calorie diets (VLCDs) contain energy levels $<800 \mathrm{kcal} /$ day with daily allowances of all essential nutritional requirements [54]. VLCDs can be designed to replace the whole diet using products (e.g., meal replacement shakes) and can be defined as a total diet replacement. In comparison, the LCD can either be a total diet replacement or the formula products can be incorporated into modified conventional meals as a partial diet replacement [55]. Macronutrient distribution varies among different approaches from very low-fat diets (about $21 \%$ protein, $8 \%$ fat and $71 \%$ carbohydrate) to low-carbohydrate diets (about $21 \%$ protein, $50 \%$ fat and $29 \%$ carbohydrate) [56].

One of the essential health outcomes for the prevention of multiple chronic diseases and the promotion of healthy aging is maintaining a healthy body weight and preventing accumulation of abdominal fat. Low-calorie regimens constitute weight loss strategies for individuals with overweight or obesity [57], a common profile in people with T2D. Weight loss produces numerous benefits such as improved glucose metabolism, reduction in glycaemia and fasting insulin levels and increased insulin sensitivity, reduction in blood pressure, and improvements in lipid profile with decreased triglycerides, increased high density lipoprotein cholesterol (HDL-C) and fewer small, dense, low density lipoprotein cholesterol (LDL-C) particles. The advantages of very low-calorie diets include rapid weight loss that could act as a motivating factor, calorie restriction-associated diuresis that can alleviate fluid retention, and probably hunger suppression by mild ketosis [58]. 
Associative evidence: Beyond weight loss, VLCDs have been associated with reductions in blood glucose and improvements in cardiovascular risk profile in people with T2D [59,60]. Findings suggest that changes in measures of diabetes control, HbA1c or fasting plasma glucose are primarily the result of weight loss. It is generally believed that higher calorie restriction leads to greater weight loss [61]. In addition, when considering rapid and substantial weight loss $(>15 \mathrm{~kg})$, emerging evidence suggests that calorie-restriction of this magnitude can lead to reversal (or remission) of T2D in effects similar to that of bariatric surgery [62]. However, sustaining a very-low calorie diet is challenging, hence the use of formula diets containing 800-900 kcal per day as meal replacements during an initial rapid weight loss phase [63].

There is still limited evidence that a VLCD can maintain weight loss over the long term. For example, meta-analysis results showed that VLCD resulted in greater weight reduction (compared to LCD) in the short-term. However, after 1 year, weight loss did not differ between dietary strategies [64].

A recent retrospective study designed to evaluate the safety, efficacy and durability of a 12 month very low-calorie ketogenic diet (VLCKD) on body weight and glycemic control in a selected group of patients with T2D and obesity showed a rapid and significant improvement in metabolic parameters, anthropometric measures and quality of life. The patients who followed a VLCKD showed a higher adherence to the prescribed nutritional regimen, compared to patients in the LCD group, probably due to the rapid weight loss and greater feeling of satiety [65]. The induction of ketosis has been associated with a greater feeling of fullness, greater tolerability, higher reduction in body fat and preservation of mean body mass [66]. Furthermore, high-ketogenic VLCDs lower glucose more than lowketogenic VLCDs in obese T2D patients, possibly by reducing hepatic glucose output [67].

Intervention studies: Even though rapid weight loss occurs from LCDs and VLCDs $[54,68]$, strict and life-long compliance to these dietary strategies is likely to be difficult to maintain. In order to improve adherence, VLCDs are generally used as part of a comprehensive intervention that includes an intensive weight loss phase with medical monitoring followed by a program of lifestyle modification $[69,70]$. The DiRECT trial, a primary care-led cluster randomized control trial, showed that a VLCD resulted in T2D remission ( $\mathrm{HbA1c}<6.5 \%$ and no glucose-lowering medications) in $46 \%$ of patients at 1-year [69] and $36 \%$ at 2 years follow up [71]. Results of the DiRECT trial highlight the concept of T2D remission which is now routinely emphasized in nutritional intervention research. In this trial, an initial phase using total meal replacement providing $\sim 850 \mathrm{kcal} /$ day through nutritional shakes, soups, and puddings was followed by a gradual food reintroduction phase with individual guidance for weight loss maintenance. Little information was provided about dietary composition during the maintenance phase at 1 and 2 years when the T2D remission data were reported, but the findings suggest a combined approach of VLCD with medical supervision and food reintroduction can produce lasting improvements in clinical T2D outcomes and possibly reverse some of the pathophysiology of the disease.

In a pilot study prior to the DiRECT trial, the Newcastle Counterpoint study achieved "reversal" of T2D with mean weight loss of $15.3 \mathrm{~kg}$ in 11 people with T2D within 4 years of diagnosis, using a $600 \mathrm{kcal} /$ day low-energy liquid diet. The normalization of fasting plasma glucose persisted for up to 3 months after return to normal diet [72].

In addition, there is evidence that short-term caloric restriction per se improves glucose control and beta-cell function in patients with T2D and class III obesity [73]. It has also been shown that VLCDs lead to discontinued medication and optimal glycemic control with improvements in insulin sensitivity and beta cell function [74]. Efficacy of VLCDs as therapeutic intervention for weight loss and metabolic improvements in individuals with T2D is promising and consolidating. The role of VLCKDs is arising in importance and could have additional effects beyond the caloric restriction by generating a ketogenic state. However, implementation and whether such diets can be, or need to be, followed long term remain as areas of investigation for these dietary patterns in patients with T2D. 


\subsection{Intermittent Fasting}

The prevention and treatment of chronic metabolic diseases through dietary approaches can also include different forms of fasting, time-restricted eating, and fasting mimicking diets with emerging evidence showing potential promise for improving clinical outcomes. These dietary practices range from time restricted eating, feeding every other day (alternate day fasting), periodic fasting ( 5 days eating: 2 days fasting), or undergoing a periodic cycle of diets that provide a relatively high caloric content but are designed to mimic many of the effects of fasting (Fasting Mimicking Diets) as presented in Table 1 [75].

Table 1. Definition of terms used to describe different types of fasting or calorie restricted eating patterns (adapted from [76]).

\begin{tabular}{|c|c|}
\hline Eating Patterns & Definition \\
\hline Intermittent Fasting & Involves fasting for varying periods of time, typically for at least $12 \mathrm{~h}$ or longer. \\
\hline Time Restricted Eating & $\begin{array}{l}\text { Involves restricting food intake to specific time periods of the day, typically between an } \\
8-12 \mathrm{~h} \text { period each day (e.g., } 16: 8 \text {, involving } 16 \mathrm{~h} \text { fasting and an } 8 \mathrm{~h} \text { eating window) }\end{array}$ \\
\hline Alternate Day Fasting & $\begin{array}{c}\text { Involves consuming no calories on fasting days and alternating fasting days with a day of } \\
\text { unrestricted food intake or "feast" day }\end{array}$ \\
\hline Alternate Day Modified Fasting & $\begin{array}{l}\text { Involves consuming less than } 25 \% \text { of baseline energy needs on "fasting" days, alternate } \\
\text { with a day of unrestricted food intake or "feast" day }\end{array}$ \\
\hline Periodic Fasting & $\begin{array}{c}\text { Consists of fasting only } 1 \text { or } 2 \text { days a week and consuming food ad libitum on } 5 \text { to } 6 \text { days } \\
\text { per week. }\end{array}$ \\
\hline Fasting Mimicking Diet & $\begin{array}{l}\text { Consists of a very low calorie (usually high fat) diet designed to replicate a fasting state, } \\
\text { often done periodically or in cycles. }\end{array}$ \\
\hline
\end{tabular}

The overall premise behind different fasting regimens is to maximize oxidation of fatty acids and ketone bodies instead of relying on glucose as a fuel source (reference required). Prolonged fasting will also result in longer periods of time where insulin levels are low, potentially assisting in weight loss and improved insulin sensitivity through reduction in hyperinsulinemia $[77,78]$. Weight loss could also be generated by lower caloric ingestion if there is no over-eating during eating days. A study examining intermittent fasting ( 5 days eating:2 days fasting) found that participants ate less than prescribed on non-fasting days $(156 \mathrm{kcal} /$ day) and composition of diets were around $22 \%$ of caloric intake from protein, $33 \%$ from fat and 39\% from carbohydrates [79].

Intermittent fasting regimens are hypothesized to influence metabolic regulation via effects on circadian biology, weight loss, the gut microbiome, and may represent modifications to lifestyle behaviors (e.g., limit eating opportunities or overall energy intake) which may positively impact T2D [80]. Animal models show improvements in health outcome measures throughout the life span while clinical studies have focused mainly on young and middle-aged adults who are considered overweight/obese [77]. However, controversy exists regarding the efficiency of intermittent fasting as skipping breakfast (arguably a form of time restricted feeding or intermittent fasting) is associated with an elevated risk of coronary heart disease, T2D and other adverse factors [81]. Furthermore, skipping breakfast is associated with much greater glycemic spikes in response to a standardized lunch and dinner in people with T2D [82] and has been shown to disrupt certain clock genes in leukocytes [83]. Thus, the overall benefits of intermittent fasting regimens for people with T2D remain somewhat uncertain.

Associative evidence: A systematic review and meta-analysis demonstrated that intermittent fasting significantly decreased body weight when compared to a standard diet but had no greater effect on HbA1c, lipid profile or blood pressure [80,84]. These results are in accordance with another recent review [85] in which no differences were found between intermittent fasting regimens and calorie restriction. The benefits in weight reduction and improvement in glycemic control in patients with T2D do not seem to be an independent effect of IF but are similar to a standard calorie-restricted diet that results in negative energy balance. 
Intervention studies: A recent review summarized five RCTs in adults with T2D and concluded that intermittent fasting and continuous energy restriction dietary practices were viable strategies for improving glycaemia and body composition measures [84]. Trepanowski et al. [86] and Sundfor et al. [87] conducted RCTs in adults with obesity and found no significant differences in weight loss, weight maintenance, or cardiovascular outcome measures when comparing alternate day fasting to daily calorie restriction. It is important to note that improvements in insulin sensitivity (reduced fasting insulin by $3.4 \pm 1.6 \mathrm{mU} / \mathrm{L}$ and mean and peak insulin values by $26 \pm 9 \mathrm{mU} / \mathrm{L}$ and $35 \pm 13 \mathrm{mU} / \mathrm{L}$ ), $\beta$-cell responsiveness (increased the insulinogenic index, a marker of $\beta$ cell responsiveness, by $14 \pm 7 \mathrm{U} / \mathrm{mg}$ ), blood pressure, oxidative stress, and appetite have been discovered in pre-diabetic individuals who practice alternate day fasting [88]. Corley et al. examined the effects of consecutive or non-consecutive day fasting (2 days/week) for 12 weeks in individuals with T2D. Results showed that both fasting practices resulted in similar reductions in weight loss, HbA1c and fasting glucose [89]. Similar results were found in a short-term pilot study indicating that intermittent fasting may be a tolerable dietary intervention in people with T2D and could improve key outcomes including body weight $(-1.395 \mathrm{~kg})$, fasting glucose and postprandial variability [90]. Other randomized controlled trials show decrease in weight, but positive glycemic outcomes are not a universal finding [61,91-93].

An important consideration for individuals with T2D who follow any intermittent fasting protocol is safety and preventing hypoglycemia due to over-medication [57]. When adopting this regimen, people with T2D and their health care providers should be careful to adjust glucose-lowering medications, which can be challenging, as there are no universal protocols and many healthcare providers (and patients) may not be used to, or trained in, medication de-escalation.

In summary, trials investigating the impacts of IF regimens on glycemic control in patients with diabetes remain limited and results from rigorous intervention trials are scarce. It is not possible to draw any clear conclusions of benefits generated by an IF approach that surpass calorie-restriction methods.

\subsection{Low-Carbohydrate and Very Low-Carbohydrate Diets}

Although gaining popularity with the general public and the subject of significant scientific research in recent years, the use of low-carbohydrate diets in treating T2D is not new. Before the advent of insulin in 1921, carbohydrate- and calorie-restriction diets were used to manage diabetes [94-96]. The use of very-low carbohydrate diets regained some popularity with Dr. Atkins' New Diet Revolution [97] and there is relatively strong evidence since then for outcomes such as weight loss and glucose management [98-102].

The American Diabetes Association and Diabetes Canada have recently acknowledged low- and very-low-carbohydrate diets as healthy options for weight loss and glycemic control in individuals with T2D [103]. The American Diabetes Association defines a lowcarbohydrate diet as having $\leq 130 \mathrm{~g}$ of carbohydrate/day and a very low-carbohydrate diet as containing $<50 \mathrm{~g}$ of carbohydrate/day [4]. Low-carbohydrate diets can be designed to be either normal-fat-high-protein $(\geq 20 \%$ of caloric intake from protein) or high-fatnormal-protein. Ketogenic diets prescribe around 70\% of caloric intake from fat, 15-20\% protein and less than 10\% carbohydrates [104]. Typically, a very low-carbohydrate diet can lead to endogenous production of ketone bodies and can be referred to as a "ketogenic" diet, although the exact level of carbohydrate intake that results in nutritional ketosis does appear to vary between individuals.

When carbohydrate content of the diet is reduced it is typical that fat and/or protein content of the diet will increase. The majority of studies tend to focus on low-carbohydrate high-fat dietary approaches, although some studies focus on low-carbohydrate high-protein diets [105-107].

The number of studies reporting low-carbohydrate diets as a successful therapy for weight loss, decreased insulin resistance, plasma glucose and use of glucose lowering medications are rising. Popular terms such as "diabetes remission" and "diabetes reversal" 
are being used to elucidate these outcomes, but the level of evidence for remission of T2D is not as strong as it is for the very low-calorie total diet replacement results from the DiRECT trial. Buse et al. [1] defined partial remission as hyperglycemia below diagnostic thresholds for diabetes for at least 1 year's duration with no active pharmacologic therapy or ongoing procedures, and complete remission as normal glycemic measures for at least 1 year's duration and no active pharmacologic therapy or ongoing procedures.

Associative evidence: A recent systematic review and meta-analysis concluded that patients adhering to low-carbohydrate diets for six months experience greater rates of diabetes remission, but long-term effects need monitoring and medication adjustments are required when compared with other diets commonly recommended for management of T2D [108]. These findings align with those of Silverii et al., who found that lowcarbohydrate diets may produce short-term improvements in $\mathrm{HbA} 1 \mathrm{c}$ and body weight, but are typically not maintained over the long term [109]. It is notable that the restriction of dietary carbohydrates is expected to lower blood glucose and $\mathrm{HbA1c}$ since consuming carbohydrates causes postprandial hyperglycemia in people with T2D [110]. The challenge among low-carbohydrate and very low-carbohydrate approaches is sustained compliance to regimens for longer period of time.

Intervention studies: Over the past 20 years, numerous studies have demonstrated the safety and efficacy of low-carbohydrate interventions for management and treatment (i.e., reducing medication use) in individuals with T2D [111]. For example, Yancy et al. showed that a low-carbohydrate diet has positive effects on body weight $(-11.1 \mathrm{~kg})$, waist measurement, $\mathrm{HbA1C}(-1.5 \%)$ and serum triglycerides $(-42 \%)$, and fasting glucose decreased by $17 \%$ in participants with T2D [112]. Moreover, Tay et al. demonstrated that a low-carbohydrate diet had positive effects on triglycerides $(-0.4 \mathrm{mmol} / \mathrm{L}), \mathrm{HDL}$ cholesterol $(+0.1 \mathrm{mmol} / \mathrm{L})$, and glycemic control $(-0.7 \mathrm{mmol} / \mathrm{L}$ in fasting glucose and $-1 \%$ in $\mathrm{HbA} 1 \mathrm{c})$, but also lowered medication requirements and attenuated diurnal blood glucose fluctuations [113].

Short-term experimental studies have progressed to longer term RCTs which include other sub-interventions beyond only dietary interventions, which can make it difficult to isolate findings to the low-carbohydrate diet per se. One of the most well publicized trials presented one year [100] and two year [114] results from T2D participants (21-65 years) after a remote care intervention including a very low-carbohydrate diet. Following 2 years of the intervention, participants experienced improvements in $\mathrm{HbA1c}(-0.9 \%)$, fasting glucose $(-1.7 \mathrm{mmol} / \mathrm{L})$ and insulin $(-11.71 \mathrm{mIU} / \mathrm{L})$, and HOMA-IR and decreased their reliance on glucose-lowering medication classes. Furthermore, a RCT in adults with obesity and T2D showed substantial weight loss, reduced HbA1c and fasting glucose with low-calorie and low-carbohydrate diets. Only the low-carbohydrate diet resulted in significant improvements in lipid profile, blood glucose stability, and reductions in diabetes medication requirements [113].

Indeed, positive metabolic outcomes occur with weight loss as a result of different dietary approaches, and not only low-carbohydrate diets [115]. In a 12-month weight loss and diet study, there was no significant difference in weight change between a healthy low-fat diet vs. healthy low-carbohydrate diet [116]. However, very low-carbohydrate diets could advance beyond weight loss outcomes (e.g., glycemic stability, reduction in glucose-lowering medication use).

It may seem that advantage is related to the degree of carbohydrate restriction, and that very low carbohydrate diets are more effective than standard low carbohydrate diets [117]. Ketone bodies resulting from low-carbohydrate diets are used by tissues as a source of energy as an evolutionary-conserved physiological mechanism related to starvation [99]. Recent work over the last decade or so has provided accumulating evidence of the possibility of the unique therapeutic potential of ketogenic diets in many pathological conditions, such as diabetes. This supposition is supported by two recent meta-analyses of low carbohydrate diets reporting that those studies with the lowest daily carbohydrate intake found the largest reduction in HbA1c [101,118]. Participants achieving and sustaining 
nutritional ketosis showed improvements in blood glucose, insulin, HbA1c, weight, blood pressure, triglyceride, liver function, and inflammation and reduced dependence upon medication [114]. In addition, the ketogenic diet was most effective in reducing body weight and improving glycemic control when compared to a standard hypocaloric diet in T2D patients $[119,120]$.

It is interesting to note that there is moderate evidence in low-carbohydrate diets as an approach that increases remission of T2D in a six-month period. Important improvements are also seen in weight loss, triglycerides, and insulin sensitivity at six months, which diminished at 12 months [108] with benefits seemingly related to the level of carbohydrate restriction, as well as compliance. Nevertheless, like other restrictive dietary patterns, long-term adherence to low-carbohydrate and very low-carbohydrate diets can be a challenge [121].

\subsection{Low Glycemic Index Diets}

Dietary recommendations have tended to emphasize the quantity rather than the quality of carbohydrate, despite the fact that carbohydrate source and type distinctly influence postprandial glycaemia. The ability of dietary carbohydrates to exacerbate postprandial plasma glucose is different and depends on their structure and fiber content. However, while dietary factors are important modifiable risk factors for T2D, the causal role of carbohydrate quality in nutrition remains controversial [122]. The glycemic index (GI) ranks the nature of carbohydrates in foods and is defined as the incremental area under the plasma glucose curve after consumption of $50 \mathrm{~g}$ test carbohydrate, compared with a reference food. Glycemic load (GL) is a qualitative and quantitative index computed by multiplying GI by the carbohydrate content of the food $(\mathrm{g} / 100 \mathrm{~g}$ or $1000 \mathrm{~kJ}$ edible food) $[123,124]$.

Various guidelines recommend prioritizing food with GI and GL considerations. Low GI and GL can be incorporated into healthy eating dietary advice and applied in the context of healthy diet and individualized nutritional orientation [122]. If carbohydrates are derived from low glycemic index and high-fiber foods, this has been shown to contribute to improvements in glycemic and lipid control in adults with T2D. However, even though diets with a low glycemic index may have beneficial effects on certain risk factors, the effectiveness of ad libitum consumption of low-glycemic-index diets for weight control is controversial and interventions usually follow health guidelines ( $45-55 \%$ carbohydrates, $10-35 \%$ protein and $20-35 \%$ fat) $[125,126]$.

Associative evidence: Prospective cohort studies provide evidence that diets higher in glycemic index (GI) and load (GL), independently of dietary fiber, substantially elevate the risk of T2D [127]. Other studies show fiber intake as an important factor in T2D prevention. In three large prospective cohorts of males and females, there was a positive association between GI, GL, and the prevalence risk of developing T2D. Participants who consumed diets with high GI or high GL and low cereal fiber had $\sim 40 \%$ higher risk of developing T2D compared with those whose diets were high in cereal fiber and low in GI or GL [128]. In fact, in most studies the low-GI diet was found to contain more fiber, making it difficult to separate the effects of the fiber per se from that of the low GI foods. Even though these limitations are noticed, there is still evidence that choosing low GI foods could be useful in targeting postprandial hyperglycemia [129].

As for people with impaired glucose tolerance or diabetes, a meta-analysis of 54 studies demonstrated that low GI diets reduce $\mathrm{HbA1c}$, fasting blood glucose, body mass index, and blood lipids. However, the analysis failed to show a significant difference between low GI diets and control diets in lowering body weight and the low-GI diets were not superior to any individual control diet [130]. However, results have also shown that high GI diets increase triglycerides and inflammatory markers. Elevated blood glucose and insulin (with a high GI diet) can induce insulin resistance, which could lead to increased triglyceride, an inflammatory response, and a decrease in HDL cholesterol [131]. 
Intervention studies: RCTs have also provided evidence that lower GI diets can improve certain metabolic parameters. For example, low GI diets were effective in lowering HbA1c levels in individuals with T2D [132], whereas increases in glycemic index (with a 1-unit change) were associated with higher $\mathrm{HbA1c}$ levels $(+0.3 \%)$ and waist circumference $(+0.12 \mathrm{~cm})$, but not with fasting glucose, blood lipids, or body mass index [133]. Another study with 20 participants with T2D found that consumption of a low GI diet for 30 consecutive days led to greater reductions in fat mass while a high GI diet caused an increase in fructo-samine, non-esterified fatty acids and TNF- $\alpha$ concentrations [134]. In a longer trial, Jenkins et al. found that a 6-month treatment with a low GI diet resulted in moderately lower $\mathrm{HbA} 1 \mathrm{c}$ levels $(-0.18 \%)$ compared with a high-cereal fiber diet in patients with T2D [135].

In patients with T2D who consumed a high-carbohydrate/high-GI diet, high-carbohydrate/ low-GI diet or low-carbohydrate/high-monounsaturated-fat diet for 1 year, significant increases in disposition index, an index of beta cell function, was observed from the low-GI diet compared to the low-carbohydrate diet. No significant results were seen for high-carbohydrate/low-GI [136].

In conclusion, a low-GI diet can help manage glucose levels and parameters associated with T2D probably due to inclusion of well-balanced, minimally processed and high in fiber foods such as whole-grain, fruits and vegetables, and protein sources. While the low-GI diet can help manage glucose levels if foods are chosen wisely, in order to achieve one of the most important outcomes related to diabetes, weight loss, low-GI dietary prescriptions still have to consider reducing daily calorie ingestion.

Figure 1 summarizes dietary strategies used to improve metabolic outcomes in Type 2 Diabetes.

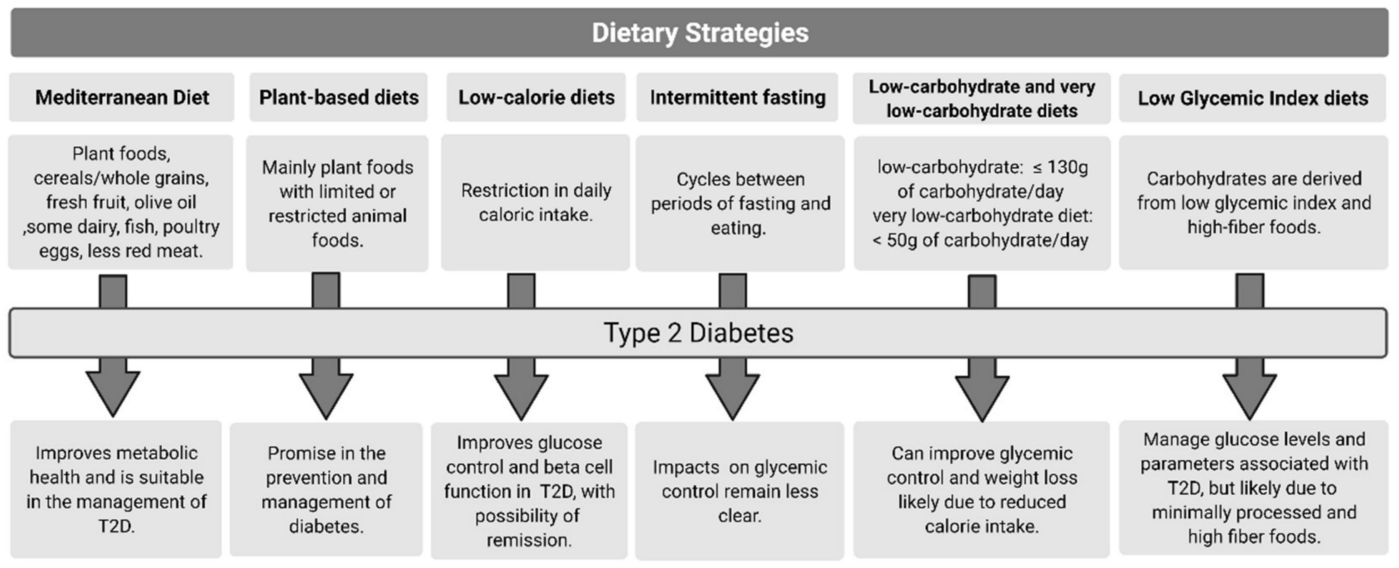

Figure 1. Dietary strategies and key outcomes for type 2 diabetes.

\section{Potential Supplements for Type 2 Diabetes}

A limitation of altering complete dietary approaches is determining which nutrient(s) is associated with improvements. The purpose of this section is to outline individual dietary supplements that are purported to be effective for individuals with T2D, with a primary focus on older adults.

\subsection{Protein Supplementation}

Dietary protein has the potential to exert beneficial effects on numerous factors which underscore disease progression in older individuals with T2D. These include supporting lean muscle mass retention and accretion (a primary characteristic of sarcopenia), thereby exerting positive influence on whole-body insulin sensitivity and thermogenesis. Furthermore, dietary protein ingestion can directly impact insulin secretion and appetite regulation, both of which are crucial factors in T2D etiology. 


\subsubsection{Dietary Protein and Lean Muscle Mass}

Skeletal muscle is the largest peripheral site for glucose disposal [137]. Cross-sectional analysis of $>13,000$ individuals revealed $10 \%$ higher lean muscle mass as a proportion of body weight which diminished relative risk of prediabetes by $23 \%$ in non-T2D individuals [138]. Considering the etiology of T2D, muscle mass retention or accretion is implicit in controlling disease manifestation. In rats, muscle hypertrophy occurs alongside improvements in glucose disposal and 63\% increase in glucose transporter protein-4 (GLUT-4) content [139]. Similarly, GLUT-4 content increases alongside gains in muscle mass and strength in T2D individuals [140]. Furthermore, in older adults with and without T2D, muscle accretion lowers myostatin (inhibitor of muscle accretion), partially restoring insulin sensitivity $[141,142]$. Given the role of adequate dietary protein as a key stimulus for muscle protein synthesis (MPS) and muscle mass retention/accretion, it is promising that longitudinal studies show inverse associations between higher protein intake and T2D development in middle-aged females [143]. Hence, adequate protein can support sustained intramuscular adaptation/remodeling for glucose handling and whole-body metabolic health.

Whilst dietary protein intake appears to be a pragmatic way to support and improve muscle mass and metabolic health in older individuals with T2D, it is important to note that protein requirements for these individuals may differ compared to younger individuals. Age-related blunted postprandial MPS (termed "anabolic resistance") is exacerbated in obese older adults [144] but not necessarily by T2D per se [145]. Irrespective, T2D and obesity are often concomitant and worsened intramuscular insulin and anabolic signaling with aging means anabolic resistance among older adults with T2D is somewhat inevitable. For robust postprandial MPS stimulation that is critical for overall net muscle protein balance, it is generally accepted that older adults require higher protein doses than young adults [146-149] at a level that is greater than the current RDA of $0.8 \mathrm{~g} / \mathrm{kg} /$ day [150]. Specifically, the dietary protein requirements for older individuals have been suggested to be at least $1.0-1.2 \mathrm{~g} / \mathrm{kg} /$ day, and potentially higher in scenarios where physical activity is reduced $[150,151]$. The same is also true for older individuals with T2D, where protein intakes for optimal muscle anabolism may be even greater than for non-obese older adults due to a potentially aggravated muscle anabolic resistance [152].

\subsubsection{Dietary Protein-Induced Thermogenesis}

Increasing dietary protein intake with the aim of supporting skeletal muscle retention in older individuals with T2D may facilitate weight management and healthy body composition with implications for thermogenesis. An increase in overall lean body mass increases metabolic rate due to loss of relatively dormant white adipose tissue and heightened energy cost associated with skeletal muscle metabolic processes [153-155]. Higher energy requirements are conducive to heat dissipation. Such loses are partially due to occasional inefficiencies in calcium release inhibition whereby, instead of moving myofibrils, energy is conserved as heat in non-shivering thermogenesis [156]. Heat can also be lost with diet-induced thermogenesis, particularly after protein ingestion [157]. Primarily however, skeletal muscle supports movements whereby greater muscle mass facilitates higher energy and heat dissipation [158]. Since positive energy balance precipitates weight gain, lowering energy balance through greater muscle mass and dietary protein consumption contributes to weight loss $[159,160]$. In turn, the reduction in body fat mass in older individuals with T2D could also, theoretically, alleviate postprandial muscle anabolic resistance and augment muscle retention over time, with implications for controlling T2D manifestation and comorbidities.

\subsubsection{Protein Ingestion and Insulinemia}

Dietary protein ingestion can directly promote postprandial insulin secretion which may facilitate glucose regulation in older individuals with T2D. The insulinotropic effects of protein are mediated by the appearance of branched-chain amino acids (BCAAs; leucine, 
isoleucine, valine) which bind to pancreatic $\beta$-cell receptors. Indeed, providing low protein diets in healthy rats diminishes insulin secretion $\sim 2$-fold compared to high-protein diets [161]. Furthermore, this insulin concentration following high-protein diets is similar when low protein diets are supplemented with leucine, valine and isoleucine [161]. In humans, whey protein elicits a robust insulin response, the peak amplitude of which was reported to be $\sim 50 \%$ and $25 \%$ greater than egg and fish ingestion, respectively [162] which can be attributed to the higher essential amino acid (EAA)/BCAA concentration of whey protein. In human trials, compared with placebo, ingesting $50 \mathrm{~g}$ of whey protein prior to a high-glycemic index breakfast elicited a $105 \%$ higher insulin secretion alongside a $28 \%$ reduction in post-prandial glycemia in older adults [163]. Despite the benefits, to minimize glucose excursions postprandially would require $50 \mathrm{~g} / \mathrm{meal}$ of supplemental protein. Consuming such large protein doses with each meal could adversely impact appetite regulation and food intake at subsequent meals, the importance of which is discussed below. More recently, $15 \mathrm{~g}$ of intact whey protein preceding mixed-macronutrient meals at breakfast and lunch, containing $70 \%$ and $65 \%$ carbohydrate, respectively, significantly lowered interstitial glucose concentration compared to control in older males with T2D [164]. The glucose lowering effect of whey protein in this study was associated with an increased insulin response over a 3-h postprandial period.

Despite evidence of dietary protein intake lowering glycemia, numerous contrasting studies report lowered insulin sensitivity with high-protein diets in adults with excess adiposity [165,166] and T2D [106]. In fact, daily $7.5 \mathrm{~g}$ leucine supplementation over 6 months failed to improve glycemic control in older adults [167]. However, this may reflect that $>7.5 \mathrm{~g}$ leucine is required to support improved glucose regulation. Some studies have reported a causal link between BCAA concentration and insulin resistance. Controlled studies have shown that lowering circulating BCAA concentrations lowers insulin concentration and improves lipolysis in middle-aged individuals with T2D [168], which could eventually restore metabolic flexibility [169]. Interestingly, in a separate cohort of middle-aged individuals with T2D, high-carbohydrate diets induced similar weight loss after 8 weeks compared to high-protein diets, yet significant improvements in insulin sensitivity were only seen with high-carbohydrate diets [170]. Conversely, increasing dietary protein to $30 \%$ of total energy intake, at the expense of carbohydrate and fat, elicits similar reductions in 10-h glucose area under the curve in individuals with T2D [171].

Although protein-induced insulinemia may acutely improve glucose handling, reports of impaired insulin sensitivity in the longer-term may be due to divergent BCAA profiles in protein sources. Recently, mouse models have identified that the BCAAs valine and isoleucine contribute to abnormal glucose handling [172]. However, all EAAs, especially leucine, are thought to be important as both signal and substrate for muscle anabolism. Henceforth, incorporating whole-food options which are high in leucine but lower in valine and isoleucine (e.g., egg, corn and wheat [173]) could benefit muscle anabolism and metabolic health outcomes, although this speculation remains to be confirmed in humans. Importantly, restricting certain protein sources is not conducive to muscle anabolism and retention or metabolic health improvements in older individuals with T2D. Alternative mechanisms to potentiate insulin secretion for glucose management relate to incretin peptides. Incretin peptides, such as glucagon-like peptide-1 (GLP-1) are secreted by the gut and bind to pancreatic cells to promote insulin secretion and inhibit glucagon secretion. Plant and animal proteins are associated with increased integrin response [174]. Henceforth, a combination of animal and plant proteins should be encouraged, as completely replacing plant for animal protein, or vice versa, would be unlikely to profoundly improve glucose handling $[175,176]$.

\subsubsection{Appetite Regulation}

Dietary protein is a highly satiating macronutrient. Appetite suppression with highprotein meals may effectively prevent or minimize calorie surplus and the excessive efflux of exogenous substrates which exacerbate T2D symptoms [177-179]. Feelings of satiety 
are derived from secretion of anorexigenic hormones, peptide YY and GLP-1. Controlled studies in humans have shown increases in peptide YY and GLP-1 negatively associate with energy intake and appetite [180-182]. Given its insulinotropic effects, GLP-1 inhibits acylated ghrelin (the 'hunger hormone'), through insulinemia [183]. Although in normal weight humans, dietary fat elicits greater postprandial secretion of peptide YY and GLP-1 than carbohydrate [184,185], this difference is less apparent in obese populations [186]. Importantly, irrespective of body mass, dietary protein is a potent secretor of peptide YY and GLP-1 and can effectively lower energy intake [187]. Considering the impact of protein ingestion on anorexigenic hormone secretion, emphasizing dietary protein intake for obese individuals with T2D may have profound benefits for appetite regulation, weight management and glycemic control.

With isolated supplemental protein sources, divergent EAA profiles and digestibility may elicit distinct appetite responses [188]. For instance, slowly digested casein protein ingestion elicited higher GLP-1 secretion than whey protein over 6-h in obese adults [189]. However, sustaining satiety beyond 6-h is often not required, as shorter time frames typically separate main meals and mid-meal snacks. Henceforth, evidence showing that whey protein increases GLP-1 and suppresses appetite to a greater extent than casein over 3-h postprandial periods [190] makes this supplemental protein source an attractive option to maintain fullness when consumed between or with meals. Comparisons of whey to isolated plant proteins remain to be elucidated, although animal and cellular models highlight that wheat and pea protein increase GLP-1 acutely [191,192], although the temporal time-course and significance for glycemic regulation has not been translated to human models. Additionally, whey protein appears to augment satiety with whole food. Consuming a breakfast containing $>50 \%$ protein from whole-foods increases satiety $\sim 6$-fold and anorexigenic hormones by $16-45 \%$ compared to lower protein breakfasts over $2-\mathrm{h}$ postprandially [193]. The co-ingestion of $15 \mathrm{~g}$ whey protein with a mixed-meal breakfast in T2D warranted $17 \%$ higher satiety than co-ingesting with an isocaloric placebo [164]. Whilst supplemental protein is the most feasible way to elevate total protein intake, a 'food first' approach should be incorporated when combatting metabolic disease. Dietary proteins are effective in prolonging fullness in obese populations [194], likely due to bioactive peptides within protein-rich food, which further augment satiety [195]. Henceforth, elevating protein intake through dietary and supplemental sources will lessen appetite response and promote fat loss through lowered energy contribution from other macronutrients in order to improve indices of T2D progression $[196,197]$.

\subsection{Branched-Chain Amino Acids}

BCAAs make up approximately $40 \%$ of circulating amino acids and play an important role in protein turnover and, as previously discussed, have an insulinotropic effect [198-200]. Due to the complications of T2D, individuals are at risk of developing sarcopenia [201]. Decreased muscle mass inhibits glucose uptake, metabolic functioning, and individual's physical capacity which may exacerbate the effects of T2D and sarcopenia. For this reason, supplementation with BCAAs may benefit individuals with T2D by stimulating insulin secretion and protein synthesis, inevitably regulating blood glucose disposal and maintaining/increasing muscle mass and function [202].

Ingestion of BCAAs increases insulin secretion from pancreatic $\beta$-cells, potentially through the incretin effect $[203,204]$. It is hypothesized that BCAAs stimulate the secretion of peptide hormones glucagon-like peptide 1 (GLP-1) and glucose dependent insulinotropic polypeptide (GIP) [203]. GLP-1 and GIP work together to simulate insulin secretion postprandially, improving glycemic control and $\beta$ cell growth while decreasing $\beta$ cell apoptosis [205]. Function of GLP-1 and GIP is compromised in T2D, but research suggests BCAA ingestion stimulates inhibited GLP-1 and GIP for improved insulin secretion $[203,204,206]$. Special consideration has been given to leucine and its metabolites due to its insulinotropic effects and stimulation of the mammalian target of rapamycin (mTOR) pathway which regulates protein synthesis, cell growth, and fuel 
metabolism [203,207-209]. Specifically, rapamycin-sensitive (mTORC1), a component of mTOR, is activated in response to an increase in cellular levels of leucine $[209,210]$. This signaling pathway elicits mRNA translation and protein synthesis while decreasing muscle wasting and cell death when activated $[208,211]$. Inhibition of mTOR signaling can occur through the activation of AMP-activated protein kinase or by upstream phosphate and tension homology. This can decrease insulin secretion, beta-cell activation and lead to the development of proinflammatory cytokines (IL-6, IL-I $\beta$, TNF- $\alpha$ ) [212]. Long term leucine supplementation can also increase insulin secretion through improved gene expression and metabolic function [213]. BCAA infusion has been shown to activate p70S6 kinase and $4 \mathrm{E}-\mathrm{BP}$, downstream protein kinases in the mTOR pathway, leading to an increased capacity for muscle protein synthesis $[214,215]$. Increased protein synthesis is greatly beneficial for individuals with T2D, as skeletal muscle can account for up to $80 \%$ of glucose uptake, which will aid in regulation of blood glucose levels and combats muscle wasting that occurs due to complications of the disease and aging [202].

\subsection{Creatine}

Supplementing with creatine, a nitrogen-containing organic acid, has been shown to alter body composition [216-220] and may potentially enhance glucose control and decrease insulin resistance [221]. Creatine is endogenously synthesized from reactions involving the amino acids arginine, glycine, and methionine in the kidneys and liver [222]. Creatine can also be consumed in the diet (1-2 g/day) primarily from red meat, seafood, and poultry [222-224] or through dietary supplements. Once creatine enters circulation, it is transported to various tissues, with the majority ( $95 \%$ ) taken up (by way of the SLC6A8 transporter) and stored in skeletal muscle, and the remaining $(\sim 5 \%)$ found in other tissues, such as cardiac myocytes, retina, neurons, and testicles. In the muscle, $\sim 2 / 3$ rd is converted to phosphocreatine ( $\mathrm{PCr}$ ) and 1/3rd remains as free creatine [222]. Following repeated muscle contractions (i.e., exercise), adenosine diphosphate (ADP) is rapidly phosphorylated by $\mathrm{PCr}$ to resynthesize adenosine triphosphate (ATP) in order to maintain energy status [225]. Creatine supplementation elevates intramuscular stores $\sim 20 \%$ more than habitual dietary practices [226,227], which in turn may increase PCr resynthesis and recovery during exercise. Creatine may influence muscle biology by stimulating cellular hydration status, calcium kinetics, glycogen content, muscle protein kinetics, satellite cells, growth factors, inflammation and oxidative stress, which have been implicated in enhancing muscle health (for reviews see $[216,220,225,228]$. Creatine also plays a role in thermogenesis and whole body energy expenditure [229-231], which is associated with adiposity.

In healthy older adults, supplementing with creatine during a resistance training program increased muscle mass $(+1.37 \mathrm{~kg})$ and decreased fat mass $(0.5 \mathrm{~kg})$ more than placebo and resistance training [218,229]. Individuals with T2D often have low muscle quantity and increased adiposity; therefore it appears that creatine combined with exercise may be a viable strategy to enhance body composition. However, research examining the efficacy of creatine and exercise individuals with T2D is limited. In female Wistar rats, creatine supplementation for 3 weeks increased glycogen content, GLUT-4 mRNA, AMPK phosphorylation, and GLUT-4 content [232]. However, in humans, van Loon et al. [233] found no effect of creatine ( $20 \mathrm{~g} /$ day for 5 days followed by $2 \mathrm{~g} /$ day for 37 days) on GLUT-4 mRNA or protein content. In an open-label, crossover design (with a short 2-day washout period) in a small sample of T2D patients, creatine ( $2 \mathrm{~g}$ provided twice a day for 5 days) had a similar glucose lowering effect as metformin [234]. Only two studies have assessed the effects of creatine in conjunction with exercise in T2D patients [235-237]. Gualano et al. [236] showed that the combination of creatine (5 g/day for 12 weeks) and exercise (aerobic and resistance training, $3 x /$ week) resulted in significant reductions in $\mathrm{HbA1c}$ and glycaemia during a meal tolerance test and increased GLUT-4 translocation compared to placebo in in older individuals ( $>50 \mathrm{yrs}$ ) with T2D. Using the same creatine and exercise intervention, Alves et al. [235] found an increase in AMPK $(p=0.06)$ which was 
associated with changes in GLUT-4 translocation and $\mathrm{Hb} 1 \mathrm{Ac}$ levels in older individuals with T2D.

Collectively, creatine supplementation and exercise have the potential to provide beneficial effects for older individuals with T2D.

\subsection{Vitamin D}

Vitamin D is a fat-soluble hormone that plays an important role in the regulation of circulating calcium and phosphates, gene transcription, inflammatory response, and glucose metabolism [238,239]. Vitamin D is endogenously produced from exposure to sunlight or obtained through dietary and/or supplementation practices [240-242]. Exogenous sources (diet or supplementation) of vitamin D exist in two forms, ergocalciferol (Vitamin $\mathrm{D}_{2}$ ) and cholecalciferol (Vitamin $\mathrm{D}_{3}$ ), whereas endogenous synthesis of vitamin $\mathrm{D}$ is referred to as vitamin $\mathrm{D}_{3}[242,243]$. Briefly, once in circulation, vitamin $\mathrm{D}$ binds with vitamin D-binding protein (DBP) and is transformed by D25-hydroxylase in the liver to 25-hyroxyvitamin D (25(OH)D) [241]. Researchers measure this form of circulating vitamin $\mathrm{D}$ as an indicator of both sun exposure and dietary vitamin D levels within the body $[238,239,243]$. Circulating $25(\mathrm{OH}) \mathrm{D}$ is converted in the kidneys, through regulation of the parathyroid hormone, by 25-hydroxyvitamin D-1alpha-hydroxylase (CYP27B1) enzyme to its active form 1,25dihydroxyvitamin $\mathrm{D}\left(1,25(\mathrm{OH})_{2} \mathrm{D}\right)$ [241]. $1,25(\mathrm{OH})_{2} \mathrm{D}$ binds to vitamin $\mathrm{D}$ receptor (VDR) which can be found in several cells including the liver, adipose tissue, skeletal muscle, and pancreatic beta cells [244].

The active form of vitamin $\mathrm{D}$ can regulate the inflammatory response by inhibiting production of pro-inflammatory cytokines (tumor necrosis factor- $\alpha$, interleukin- $1 \beta$ and interleukin-6) and upregulates anti-inflammatory cytokines (interleukin-6) $[245,246]$. Inflammation in conjunction with prolonged hyperglycemia leads to over production of reactive oxygen species within the body, causing oxidative stress and microvascular and macrovascular complications [247]. In individuals with T2D, chronic low-grade inflammation is found in the liver, skeletal muscle, adipose tissue and pancreas which can cause tissue damage, further impairing the body's ability to regulate insulin levels [248].

Vitamin D deficiency can result from decreased utilization of available vitamin D in the body, inadequate dietary intake, decreased efficiency of cutaneous synthesis with age, geographic latitude, and/or limited sun exposure due to season, time of the day, and weather conditions [243]. Low levels of circulating vitamin D have been shown to be inversely related to BMI, and it is suggested the majority of vitamin D, as a fat-soluble hormone, may become sequestered in adipose tissue decreasing circulating levels [249]. An inverse relationship has also been indicated between vitamin D deficiency and insulin resistance and impaired beta cell function $[250,251]$. Vitamin D deficiency is prevalent in individuals with T2D and may pay a key role in the onset of the disease by impacting insulin secretion, fasting glucose levels, and systemic inflammation [252-254]. Deficiency in individuals with T2D is associated with impaired glucose homeostasis and both microvascular and macrovascular complications [255]. Observational studies have found a heightened risk for incidents of diabetes, of up to $50 \%$, for individuals in the lowest category of vitamin D serum levels versus the highest [256,257].

Currently a consensus on the optimal vitamin D concentration or supplementation for deficiency does not exist $[258,259]$. The Scandinavian Nutrition Societies, the European Society for clinical and Economic Aspect of Osteoporosis and Osteoarthritis, the North American Institute of Medicine, the German Osteology governing body (DVO) and D-A$\mathrm{CH}$ nutrition societies have agreed that a circulating level of $25(\mathrm{OH}) \mathrm{D}$ should not be lower than $50 \mathrm{nmol} / \mathrm{L}$, and below $25-30 \mathrm{nmol} / \mathrm{L}$ indicates deficiency [246,260,261].

Studies investigating the efficacy of vitamin D supplementation have demonstrated significant effects on circulating vitamin $\mathrm{D}$, total cholesterol, glycated hemoglobin (HbA1c), low density lipoproteins (LDL), homeostatic model assessment (HOMA-IR), and triglyceride levels, all leading to improving metabolic pathways and insulin resistance [246,262]. It is suggested that vitamin D supplementation in individuals with T2D may need to 
be significantly higher to achieve an adequate $25(\mathrm{OH}) \mathrm{D}$ levels due to the increased amount of adipose tissue and lower base vitamin D levels [258,263]. A review conducted by Li et al. [258] found that most studies in individuals with T2D used vitamin D at $2000 \mathrm{IU} /$ day, which elicited improvements in glycemic control. A meta-analysis review by Mirhosseini et al. [262] suggested a minimal dose of $4000 \mathrm{IU} /$ day was required to elicit positive effects on $\mathrm{HbA1c}$, HOMA-IR, fasting plasma glucose, and to reach an adequate level of circulating 25(OH)D. Additional systematic reviews report improvements in insulin resistance and fasting plasma glucose following vitamin D supplementation in individuals with T2D [253,264,265]; whereas Morieira-Lucas et al. [266] found a significant increase in $25(\mathrm{OH}) \mathrm{D}$ but no changes in beta cell function, $\mathrm{HbA1c}$, or fasting insulin following 24 weeks of $4000 \mathrm{IU}$ of vitamin D supplementation. These results mirror a study conducted by Wagner et al. [267] showing no change in insulin sensitivity or glucose tolerance from 30,000 IU/week of vitamin D supplementation. The difference in results may be attributed to due to study duration, sample size, and various dosage levels of vitamin d [253,264,265]. It is also important to note that excessive ingestion of vitamin $\mathrm{D}$ can be toxic and cause hypercalcemia and hypercalciuria $[268,269]$. Figure 2 summarizes dietary strategies used to improve metabolic outcomes in Type 2 Diabetes.

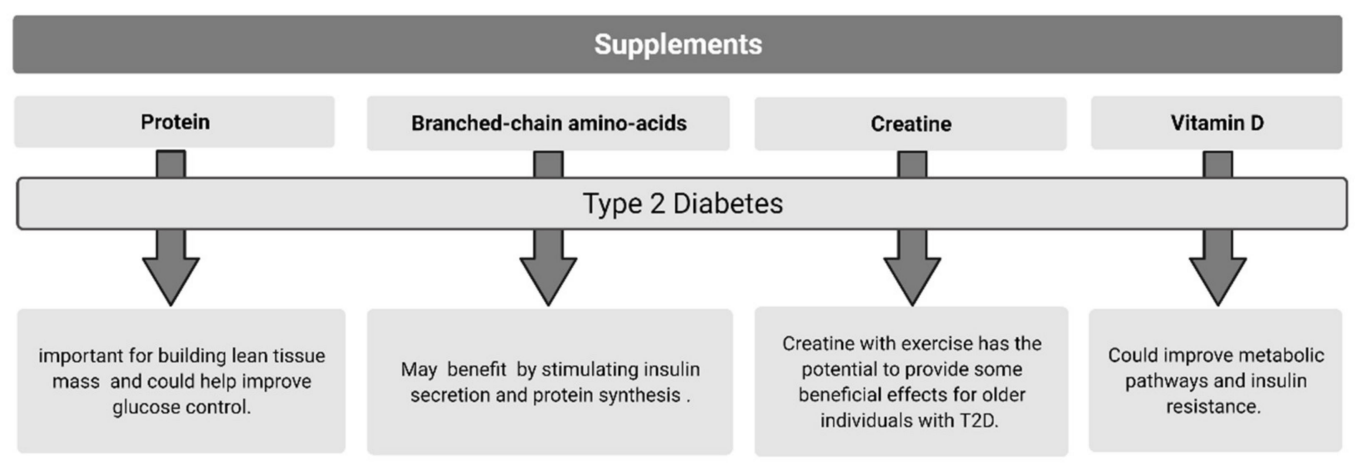

Figure 2. Purported supplements to improve type 2 diabetes.

\section{Conclusions}

Overall, there appears to be some overlapping beneficial effects from various dietary and supplementation interventions in individuals with T2D. The MedDiet improves metabolic health and is suitable in the management of T2D. A plant-based diet shows promise in the prevention and management of diabetes and its complications but still requires further investigation. Over the short-term, caloric restriction improves glucose control and beta cell function in individuals with T2D, with the possibility of T2D remission seen with very low-calorie diets. The impacts of IF on glycemic control remain less clear. Low-carbohydrate and very low-carbohydrate diets can improve glycemic control and, at least in the shorter term, result in weight loss likely due to reduced calorie intake. A low-GI diet appears to help manage glucose levels and parameters associated with T2D, but is most likely to be due to the inclusion of well-balanced, minimally processed and high fiber foods. Furthermore, protein intake greater than the RDA is important for building lean tissue mass (main tissue of glucose disposal) and could help improve glucose control through multiple mechanisms. Lastly, BCAA, creatine, and vitamin D appear to show promise for individuals with T2D, but further research, especially long-term RCTs, is needed before consensus on the efficacy of these select supplements for individuals with T2D can be arrived at.

Funding: This research received no external funding.

Conflicts of Interest: D.G.C. has conducted industry sponsored research involving creatine supplementation, received creatine donation for scientific studies and travel support for presentations involving creatine supplementation at scientific conferences. In addition, D.G.C. serves on the Scientific Advisory Board for Alzchem (a company which manufactures creatine). All of other 
authors declare no conflicts of interest with respect to the research, authorship and/or publication of this article. J.P.L. is volunteer chief scientific officer for the not-for-profit Institute for Personalized Therapeutic Nutrition and holds founders shares in the for-profit company, Metabolic Insights Inc.

\section{References}

1. Buse, J.B.; Caprio, S.; Cefalu, W.T.; Ceriello, A.; Del Prato, S.; Inzucchi, S.E.; McLaughlin, S.; Phillips, G.L.; Robertson, R.P.; Rubino, F.; et al. How do we define cure of diabetes? Diabetes Care 2009, 32, 2133-2135. [CrossRef]

2. Wild, S.; Roglic, G.; Green, A.; Sicree, R.; King, H. Global prevalence of diabetes: Estimates for the year 2000 and projections for 2030. Diabetes Care 2004, 27, 1047-1053. [CrossRef] [PubMed]

3. Akushevich, I.; Yashkin, A.P.; Kravchenko, J.; Fang, F.; Arbeev, K.; Sloan, F.; Yashin, A.I. Identifying the causes of the changes in the prevalence patterns of diabetes in older U.S. adults: A new trend partitioning approach. J. Diabetes Complicat. 2018, 32, 362-367. [CrossRef]

4. American Diabetes Association; Bantle, J.P.; Wylie-Rosett, J.; Albright, A.L.; Apovian, C.M.; Clark, N.G.; Franz, M.J.; Hoogwerf, B.J.; Lichtenstein, A.H.; Mayer-Davis, E.; et al. Nutrition recommendations and interventions for diabetes: A position statement of the American Diabetes Association. Diabetes Care 2008, 31 (Suppl. 1), 61.

5. Kirkman, M.S.; Briscoe, V.J.; Clark, N.; Haas, L.B.; Halter, J.B.; Huang, E.S.; Korytkowski, M.T.; Munshi, M.N.; Odegard, P.S.; Pratley, R.E.; et al. Consensus Development Conference on Diabetes and Older Adults Diabetes in older adults: A consensus report. J. Am. Geriatr. Soc. 2012, 60, 2342-2356. [CrossRef] [PubMed]

6. Kahn, S.E.; Cooper, M.E.; Del Prato, S. Pathophysiology and treatment of type 2 diabetes: Perspectives on the past, present, and future. Lancet 2014, 383, 1068-1083. [CrossRef]

7. Keys, A. Seven Countries A Multivariate Analysis of Death and Coronary Heart Disease; Havard University Press: Cambridge, MA, USA, 1980.

8. Dernini, S.; Berry, E.M. Mediterranean Diet; Springer: Berlin/Heidelberg, Germany, 2016; pp. $29-41$.

9. UNESCO. Available online: https://ich.unesco.org/en/RL/mediterranean-diet-00884 (accessed on 20 May 2021).

10. Willett, W.C.; Sacks, F.; Trichopoulou, A.; Drescher, G.; Ferro-Luzzi, A.; Helsing, E.; Trichopoulos, D. Mediterranean diet pyramid: A cultural model for healthy eating. Am. J. Clin. Nutr. 1995, 61, 1402S-1406S. [CrossRef]

11. Trichopoulou, A.; Vasilopoulou, E. Mediterranean diet and longevity. Br. J. Nutr. 2000, 84 (Suppl. 2), 205. [CrossRef] [PubMed]

12. Trichopoulou, A.; Costacou, T.; Bamia, C.; Trichopoulos, D. Adherence to a Mediterranean diet and survival in a Greek population. N. Engl. J. Med. 2003, 348, 2599-2608. [CrossRef]

13. Tognon, G.; Rothenberg, E.; Eiben, G.; Sundh, V.; Winkvist, A.; Lissner, L. Does the Mediterranean diet predict longevity in the elderly? A Swedish perspective. Age 2011, 33, 439-450. [CrossRef]

14. Puchalska, P.; Crawford, P.A. Multi-dimensional Roles of Ketone Bodies in Fuel Metabolism, Signaling, and Therapeutics. Cell. Metab. 2017, 25, 262-284. [CrossRef] [PubMed]

15. Esposito, K.; Giugliano, D. Mediterranean diet and type 2 diabetes. Diabetes Metab. Res. Rev. 2014, 30 (Suppl. 1), 34-40. [CrossRef] [PubMed]

16. Esposito, K.; Maiorino, M.I.; Bellastella, G.; Chiodini, P.; Panagiotakos, D.; Giugliano, D. A journey into a Mediterranean diet and type 2 diabetes: A systematic review with meta-analyses. BMJ Open 2015, 5, e008222. [CrossRef] [PubMed]

17. Guasch-Ferre, M.; Merino, J.; Sun, Q.; Fito, M.; Salas-Salvado, J. Dietary Polyphenols, Mediterranean Diet, Prediabetes, and Type 2 Diabetes: A Narrative Review of the Evidence. Oxid. Med. Cell. Longev. 2017, 2017, 6723931. [CrossRef]

18. Villani, A.; Sultana, J.; Doecke, J.; Mantzioris, E. Differences in the interpretation of a modernized Mediterranean diet prescribed in intervention studies for the management of type 2 diabetes: How closely does this align with a traditional Mediterranean diet? Eur. J. Nutr. 2019, 58, 1369-1380. [CrossRef]

19. Schwingshackl, L.; Chaimani, A.; Hoffmann, G.; Schwedhelm, C.; Boeing, H. A network meta-analysis on the comparative efficacy of different dietary approaches on glycaemic control in patients with type 2 diabetes mellitus. Eur. J. Epidemiol. 2018, 33, 157-170. [CrossRef]

20. Becerra-Tomas, N.; Blanco Mejia, S.; Viguiliouk, E.; Khan, T.; Kendall, C.W.C.; Kahleova, H.; Rahelic, D.; Sievenpiper, J.L.; Salas-Salvado, J. Mediterranean diet, cardiovascular disease and mortality in diabetes: A systematic review and meta-analysis of prospective cohort studies and randomized clinical trials. Crit. Rev. Food Sci. Nutr. 2020, 60, 1207-1227. [CrossRef]

21. Greco, M.; Chiefari, E.; Montalcini, T.; Accattato, F.; Costanzo, F.S.; Pujia, A.; Foti, D.; Brunetti, A.; Gulletta, E. Early effects of a hypocaloric, Mediterranean diet on laboratory parameters in obese individuals. Mediat. Inflamm. 2014, 2014, 750860. [CrossRef] [PubMed]

22. Vitale, M.; Masulli, M.; Calabrese, I.; Rivellese, A.A.; Bonora, E.; Signorini, S.; Perriello, G.; Squatrito, S.; Buzzetti, R.; Sartore, G.; et al. TOSCA IT Study Group Impact of a Mediterranean Dietary Pattern and Its Components on Cardiovascular Risk Factors, Glucose Control, and Body Weight in People with Type 2 Diabetes: A Real-Life Study. Nutrients 2018, 10, 1067. [CrossRef] [PubMed]

23. Maiorino, M.I.; Bellastella, G.; Petrizzo, M.; Scappaticcio, L.; Giugliano, D.; Esposito, K. Mediterranean diet cools down the inflammatory milieu in type 2 diabetes: The MEDITA randomized controlled trial. Endocrine 2016, 54, 634-641. [CrossRef]

24. Delgado-Lista, J.; Perez-Martinez, P.; Garcia-Rios, A.; Alcala-Diaz, J.F.; Perez-Caballero, A.I.; Gomez-Delgado, F.; Fuentes, F.; Quintana-Navarro, G.; Lopez-Segura, F.; Ortiz-Morales, A.M.; et al. CORonary Diet Intervention with Olive oil and cardiovascular 
PREVention study (the CORDIOPREV study): Rationale, methods, and baseline characteristics: A clinical trial comparing the efficacy of a Mediterranean diet rich in olive oil versus a low-fat diet on cardiovascular disease in coronary patients. Am. Heart J. 2016, 177, 42-50. [PubMed]

25. Gomez-Marin, B.; Gomez-Delgado, F.; Lopez-Moreno, J.; Alcala-Diaz, J.F.; Jimenez-Lucena, R.; Torres-Pena, J.D.; Garcia-Rios, A.; Ortiz-Morales, A.M.; Yubero-Serrano, E.M.; Del Mar Malagon, M.; et al. Long-term consumption of a Mediterranean diet improves postprandial lipemia in patients with type 2 diabetes: The Cordioprev randomized trial. Am. J. Clin. Nutr. 2018, 108, 963-970. [CrossRef]

26. Estruch, R.; Martinez-Gonzalez, M.A.; Corella, D.; Salas-Salvado, J.; Fito, M.; Chiva-Blanch, G.; Fiol, M.; Gomez-Gracia, E.; Aros, F.; Lapetra, J.; et al. PREDIMED Study Investigators Effect of a high-fat Mediterranean diet on bodyweight and waist circumference: A prespecified secondary outcomes analysis of the PREDIMED randomised controlled trial. Lancet Diabetes Endocrinol. 2019, 7, e6-e17. [CrossRef]

27. Salas-Salvado, J.; Guasch-Ferre, M.; Lee, C.H.; Estruch, R.; Clish, C.B.; Ros, E. Protective Effects of the Mediterranean Diet on Type 2 Diabetes and Metabolic Syndrome. J. Nutr. 2015, 146, 920S-927S. [CrossRef]

28. Salas-Salvado, J.; Diaz-Lopez, A.; Ruiz-Canela, M.; Basora, J.; Fito, M.; Corella, D.; Serra-Majem, L.; Warnberg, J.; Romaguera, D.; Estruch, R.; et al. PREDIMED-Plus investigators Effect of a Lifestyle Intervention Program with Energy-Restricted Mediterranean Diet and Exercise on Weight Loss and Cardiovascular Risk Factors: One-Year Results of the PREDIMED-Plus Trial. Diabetes Care 2019, 42, 777-788.

29. Shai, I.; Schwarzfuchs, D.; Henkin, Y.; Shahar, D.R.; Witkow, S.; Greenberg, I.; Golan, R.; Fraser, D.; Bolotin, A.; Vardi, H.; et al. Dietary Intervention Randomized Controlled Trial (DIRECT) Group Weight loss with a low-carbohydrate, Mediterranean, or low-fat diet. N. Engl. J. Med. 2008, 359, 229-241. [CrossRef]

30. Ben-Avraham, S.; Harman-Boehm, I.; Schwarzfuchs, D.; Shai, I. Dietary strategies for patients with type 2 diabetes in the era of multi-approaches; review and results from the Dietary Intervention Randomized Controlled Trial (DIRECT). Diabetes Res. Clin. Pract. 2009, 86 (Suppl. 1), 41. [CrossRef]

31. Papadaki, A.; Nolen-Doerr, E.; Mantzoros, C.S. The Effect of the Mediterranean Diet on Metabolic Health: A Systematic Review and Meta-Analysis of Controlled Trials in Adults. Nutrients 2020, 12, 3342. [CrossRef]

32. Sofi, F.; Cesari, F.; Abbate, R.; Gensini, G.F.; Casini, A. Adherence to Mediterranean diet and health status: Meta-analysis. BMJ 2008, 337, a1344. [CrossRef] [PubMed]

33. Medawar, E.; Huhn, S.; Villringer, A.; Veronica Witte, A. The effects of plant-based diets on the body and the brain: A systematic review. Transl. Psychiatry 2019, 9, 226. [CrossRef]

34. Turner-McGrievy, G.M.; Davidson, C.R.; Wingard, E.E.; Wilcox, S.; Frongillo, E.A. Comparative effectiveness of plant-based diets for weight loss: A randomized controlled trial of five different diets. Nutrition 2015, 31, 350-358. [CrossRef] [PubMed]

35. Tuso, P.J.; Ismail, M.H.; Ha, B.P.; Bartolotto, C. Nutritional update for physicians: Plant-based diets. Perm. J. 2013, 17, 61-66. [CrossRef] [PubMed]

36. Rinaldi, S.; Campbell, E.E.; Fournier, J.; O'Connor, C.; Madill, J. A Comprehensive Review of the Literature Supporting Recommendations from the Canadian Diabetes Association for the Use of a Plant-Based Diet for Management of Type 2 Diabetes. Can. J. Diabetes 2016, 40, 471-477. [CrossRef]

37. Popkin, B.M. Nutrition Transition and the Global Diabetes Epidemic. Curr. Diab Rep. 2015, 15, 64. [CrossRef] [PubMed]

38. Qian, F.; Liu, G.; Hu, F.B.; Bhupathiraju, S.N.; Sun, Q. Association Between Plant-Based Dietary Patterns and Risk of Type 2 Diabetes: A Systematic Review and Meta-analysis. JAMA Intern. Med. 2019, 179, 1335-1344. [CrossRef]

39. Barnard, N.D.; Cohen, J.; Jenkins, D.J.; Turner-McGrievy, G.; Gloede, L.; Jaster, B.; Seidl, K.; Green, A.A.; Talpers, S. A low-fat vegan diet improves glycemic control and cardiovascular risk factors in a randomized clinical trial in individuals with type 2 diabetes. Diabetes Care 2006, 29, 1777-1783. [CrossRef]

40. Huang, R.Y.; Huang, C.C.; Hu, F.B.; Chavarro, J.E. Vegetarian Diets and Weight Reduction: A Meta-Analysis of Randomized Controlled Trials. J. Gen. Intern. Med. 2016, 31, 109-116. [CrossRef]

41. Kim, H.; Caulfield, L.E.; Garcia-Larsen, V.; Steffen, L.M.; Coresh, J.; Rebholz, C.M. Plant-Based Diets Are Associated with a Lower Risk of Incident Cardiovascular Disease, Cardiovascular Disease Mortality, and All-Cause Mortality in a General Population of Middle-Aged Adults. J. Am. Heart Assoc. 2019, 8, e012865. [CrossRef] [PubMed]

42. Satija, A.; Bhupathiraju, S.N.; Spiegelman, D.; Chiuve, S.E.; Manson, J.E.; Willett, W.; Rexrode, K.M.; Rimm, E.B.; Hu, F.B. Healthful and Unhealthful Plant-Based Diets and the Risk of Coronary Heart Disease in U.S. Adults. J. Am. Coll. Cardiol. 2017, 70, 411-422. [CrossRef]

43. Trautwein, E.A.; McKay, S. The Role of Specific Components of a Plant-Based Diet in Management of Dyslipidemia and the Impact on Cardiovascular Risk. Nutrients 2020, 12, 2671. [CrossRef]

44. American Heart Association Nutrition Committee; Lichtenstein, A.H.; Appel, L.J.; Brands, M.; Carnethon, M.; Daniels, S.; Franch, H.A.; Franklin, B.; Kris-Etherton, P.; Harris, W.S.; et al. Diet and lifestyle recommendations revision 2006: A scientific statement from the American Heart Association Nutrition Committee. Circulation 2006, 114, 82-96. [CrossRef]

45. Davies, M.J.; D’Alessio, D.A.; Fradkin, J.; Kernan, W.N.; Mathieu, C.; Mingrone, G.; Rossing, P.; Tsapas, A.; Wexler, D.J.; Buse, J.B. Management of hyperglycaemia in type 2 diabetes, 2018. A consensus report by the American Diabetes Association (ADA) and the European Association for the Study of Diabetes (EASD). Diabetologia 2018, 61, 2461-2498. [CrossRef] 
46. Johannesen, C.O.; Dale, H.F.; Jensen, C.; Lied, G.A. Effects of Plant-Based Diets on Outcomes Related to Glucose Metabolism: A Systematic Review. Diabetes Metab. Syndr. Obes. 2020, 13, 2811-2822. [CrossRef] [PubMed]

47. Wright, N.; Wilson, L.; Smith, M.; Duncan, B.; McHugh, P. The BROAD study: A randomised controlled trial using a whole food plant-based diet in the community for obesity, ischaemic heart disease or diabetes. Nutr. Diabetes 2017, 7, e256. [CrossRef]

48. Pawlak, R. Vegetarian Diets in the Prevention and Management of Diabetes and Its Complications. Diabetes Spectr. 2017, 30, 82-88. [CrossRef] [PubMed]

49. Evans, F.A.; Strang, J.M. A departure from the usual methods in treating obesity. 1929. Obes. Res. 1995, 3, 210-214. [CrossRef] [PubMed]

50. Madeo, F.; Carmona-Gutierrez, D.; Hofer, S.J.; Kroemer, G. Caloric Restriction Mimetics against Age-Associated Disease: Targets, Mechanisms, and Therapeutic Potential. Cell. Metab. 2019, 29, 592-610. [CrossRef] [PubMed]

51. Heilbronn, L.K.; Ravussin, E. Calorie restriction and aging: Review of the literature and implications for studies in humans. Am. J. Clin. Nutr. 2003, 78, 361-369. [CrossRef]

52. Wadden, T.A.; Stunkard, A.J.; Brownell, K.D. Very low calorie diets: Their efficacy, safety, and future. Ann. Intern. Med. 1983, 99, 675-684. [CrossRef]

53. Koubova, J.; Guarente, L. How does calorie restriction work? Genes Dev. 2003, 17, 313-321. [CrossRef]

54. Hemmingsson, E.; Johansson, K.; Eriksson, J.; Sundstrom, J.; Neovius, M.; Marcus, C. Weight loss and dropout during a commercial weight-loss program including a very-low-calorie diet, a low-calorie diet, or restricted normal food: Observational cohort study. Am. J. Clin. Nutr. 2012, 96, 953-961. [CrossRef]

55. Brown, A.; Leeds, A.R. Very low-energy and low-energy formula diets: Effects on weight loss, obesity co-morbidities and type 2 diabetes remission-An update on the evidence for their use in clinical practice. Nutr. Bull. 2019, 44, 7-24. [CrossRef]

56. Hall, K.D.; Bemis, T.; Brychta, R.; Chen, K.Y.; Courville, A.; Crayner, E.J.; Goodwin, S.; Guo, J.; Howard, L.; Knuth, N.D.; et al. Calorie for Calorie, Dietary Fat Restriction Results in More Body Fat Loss than Carbohydrate Restriction in People with Obesity. Cell. Metab. 2015, 22, 427-436. [CrossRef] [PubMed]

57. Zubrzycki, A.; Cierpka-Kmiec, K.; Kmiec, Z.; Wronska, A. The role of low-calorie diets and intermittent fasting in the treatment of obesity and type-2 diabetes. J. Physiol. Pharmacol. 2018, 69. [CrossRef]

58. Baker, S.; Jerums, G.; Proietto, J. Effects and clinical potential of very-low-calorie diets (VLCDs) in type 2 diabetes. Diabetes Res. Clin. Pract. 2009, 85, 235-242. [CrossRef]

59. Huang, Y.S.; Zheng, Q.; Yang, H.; Fu, X.; Zhang, X.; Xia, C.; Zhu, Z.; Liu, Y.N.; Liu, W.J. Efficacy of Intermittent or Continuous Very Low-Energy Diets in Overweight and Obese Individuals with Type 2 Diabetes Mellitus: A Systematic Review and Meta-Analyses. J. Diabetes Res. 2020, 2020, 4851671. [CrossRef] [PubMed]

60. Sellahewa, L.; Khan, C.; Lakkunarajah, S.; Idris, I. A Systematic Review of Evidence on the Use of Very Low Calorie Diets in People with Diabetes. Curr. Diabetes Rev. 2017, 13, 35-46. [CrossRef] [PubMed]

61. Kloecker, D.E.; Zaccardi, F.; Baldry, E.; Davies, M.J.; Khunti, K.; Webb, D.R. Efficacy of low- and very-low-energy diets in people with type 2 diabetes mellitus: A systematic review and meta-analysis of interventional studies. Diabetes Obes. Metab. 2019, 21, 1695-1705. [CrossRef] [PubMed]

62. Hallberg, S.J.; Gershuni, V.M.; Hazbun, T.L.; Athinarayanan, S.J. Reversing Type 2 Diabetes: A Narrative Review of the Evidence. Nutrients 2019, 11, 766. [CrossRef]

63. Lowe, D.A.; Wu, N.; Rohdin-Bibby, L.; Moore, A.H.; Kelly, N.; Liu, Y.E.; Philip, E.; Vittinghoff, E.; Heymsfield, S.B.; Olgin, J.E.; et al. Effects of Time-Restricted Eating on Weight Loss and Other Metabolic Parameters in Women and Men with Overweight and Obesity: The TREAT Randomized Clinical Trial. JAMA Intern. Med. 2020, 180, 1491-1499. [CrossRef]

64. Tsai, A.G.; Wadden, T.A. The evolution of very-low-calorie diets: An update and meta-analysis. Obesity 2006, 14, 1283-1293. [CrossRef]

65. Moriconi, E.; Camajani, E.; Fabbri, A.; Lenzi, A.; Caprio, M. Very-Low-Calorie Ketogenic Diet as a Safe and Valuable Tool for Long-Term Glycemic Management in Patients with Obesity and Type 2 Diabetes. Nutrients 2021, 13, 758. [CrossRef]

66. Moreno, B.; Bellido, D.; Sajoux, I.; Goday, A.; Saavedra, D.; Crujeiras, A.B.; Casanueva, F.F. Comparison of a very low-calorieketogenic diet with a standard low-calorie diet in the treatment of obesity. Endocrine 2014, 47, 793-805. [CrossRef] [PubMed]

67. Gumbiner, B.; Wendel, J.A.; McDermott, M.P. Effects of diet composition and ketosis on glycemia during very-low-energy-diet therapy in obese patients with non-insulin-dependent diabetes mellitus. Am. J. Clin. Nutr. 1996, 63, 110-115. [CrossRef] [PubMed]

68. Schubel, R.; Nattenmuller, J.; Sookthai, D.; Nonnenmacher, T.; Graf, M.E.; Riedl, L.; Schlett, C.L.; von Stackelberg, O.; Johnson, T.; Nabers, D.; et al. Effects of intermittent and continuous calorie restriction on body weight and metabolism over 50 wk: A randomized controlled trial. Am. J. Clin. Nutr. 2018, 108, 933-945. [CrossRef] [PubMed]

69. Lean, M.E.; Leslie, W.S.; Barnes, A.C.; Brosnahan, N.; Thom, G.; McCombie, L.; Peters, C.; Zhyzhneuskaya, S.; Al-Mrabeh, A.; Hollingsworth, K.G.; et al. Primary care-led weight management for remission of type 2 diabetes (DiRECT): An open-label, cluster-randomised trial. Lancet 2018, 391, 541-551. [CrossRef]

70. Wadden, T.A.; Hollander, P.; Klein, S.; Niswender, K.; Woo, V.; Hale, P.M.; Aronne, L. NN8022-1923 Investigators Weight maintenance and additional weight loss with liraglutide after low-calorie-diet-induced weight loss: The SCALE Maintenance randomized study. Int. J. Obes. 2013, 37, 1443-1451. [CrossRef] 
71. Lean, M.E.J.; Leslie, W.S.; Barnes, A.C.; Brosnahan, N.; Thom, G.; McCombie, L.; Peters, C.; Zhyzhneuskaya, S.; Al-Mrabeh, A.; Hollingsworth, K.G.; et al. Durability of a primary care-led weight-management intervention for remission of type 2 diabetes: 2-year results of the DiRECT open-label, cluster-randomised trial. Lancet Diabetes Endocrinol. 2019, 7, 344-355. [CrossRef]

72. Weiss, R.; Taksali, S.E.; Tamborlane, W.V.; Burgert, T.S.; Savoye, M.; Caprio, S. Predictors of changes in glucose tolerance status in obese youth. Diabetes Care 2005, 28, 902-909. [CrossRef]

73. Malandrucco, I.; Pasqualetti, P.; Giordani, I.; Manfellotto, D.; De Marco, F.; Alegiani, F.; Sidoti, A.M.; Picconi, F.; Di Flaviani, A.; Frajese, G.; et al. Very-low-calorie diet: A quick therapeutic tool to improve beta cell function in morbidly obese patients with type 2 diabetes. Am. J. Clin. Nutr. 2012, 95, 609-613. [CrossRef]

74. Umphonsathien, M.; Prutanopajai, P.; Aiam-O-Ran, J.; Thararoop, T.; Karin, A.; Kanjanapha, C.; Jiamjarasrangsi, W.; Khovidhunkit, $\mathrm{W}$. Immediate and long-term effects of a very-low-calorie diet on diabetes remission and glycemic control in obese Thai patients with type 2 diabetes mellitus. Food Sci. Nutr. 2019, 7, 1113-1122. [CrossRef]

75. Longo, V.D.; Panda, S. Fasting, Circadian Rhythms, and Time-Restricted Feeding in Healthy Lifespan. Cell. Metab. 2016, 23, 1048-1059. [CrossRef]

76. Anton, S.D.; Moehl, K.; Donahoo, W.T.; Marosi, K.; Lee, S.A.; Mainous, A.G.; Leeuwenburgh, C.; Mattson, M.P. Flipping the Metabolic Switch: Understanding and Applying the Health Benefits of Fasting. Obesity 2018, 26, 254-268. [CrossRef]

77. de Cabo, R.; Mattson, M.P. Effects of Intermittent Fasting on Health, Aging, and Disease. N. Engl. J. Med. 2019, $381,2541-2551$. [CrossRef]

78. Templeman, N.M.; Flibotte, S.; Chik, J.H.L.; Sinha, S.; Lim, G.E.; Foster, L.J.; Nislow, C.; Johnson, J.D. Reduced Circulating Insulin Enhances Insulin Sensitivity in Old Mice and Extends Lifespan. Cell. Rep. 2017, 20, 451-463. [CrossRef] [PubMed]

79. Scholtens, E.L.; Krebs, J.D.; Corley, B.T.; Hall, R.M. Intermittent fasting 5:2 diet: What is the macronutrient and micronutrient intake and composition? Clin. Nutr. 2020, 39, 3354-3360. [CrossRef] [PubMed]

80. Patterson, R.E.; Sears, D.D. Metabolic Effects of Intermittent Fasting. Annu. Rev. Nutr. 2017, 37, 371-393. [CrossRef] [PubMed]

81. Cahill, L.E.; Chiuve, S.E.; Mekary, R.A.; Jensen, M.K.; Flint, A.J.; Hu, F.B.; Rimm, E.B. Prospective study of breakfast eating and incident coronary heart disease in a cohort of male US health professionals. Circulation 2013, 128, 337-343. [CrossRef] [PubMed]

82. Jakubowicz, D.; Wainstein, J.; Ahren, B.; Landau, Z.; Bar-Dayan, Y.; Froy, O. Fasting until noon triggers increased postprandial hyperglycemia and impaired insulin response after lunch and dinner in individuals with type 2 diabetes: A randomized clinical trial. Diabetes Care 2015, 38, 1820-1826. [CrossRef]

83. Jakubowicz, D.; Wainstein, J.; Landau, Z.; Raz, I.; Ahren, B.; Chapnik, N.; Ganz, T.; Menaged, M.; Barnea, M.; Bar-Dayan, Y.; et al. Influences of Breakfast on Clock Gene Expression and Postprandial Glycemia in Healthy Individuals and Individuals with Diabetes: A Randomized Clinical Trial. Diabetes Care 2017, 40, 1573-1579. [CrossRef] [PubMed]

84. Vitale, R.; Kim, Y. The Effects of Intermittent Fasting on Glycemic Control and Body Composition in Adults with Obesity and Type 2 Diabetes: A Systematic Review. Metab. Syndr. Relat. Disord. 2020, 18, 450-461. [CrossRef]

85. Rajpal, A.; Ismail-Beigi, F. Intermittent fasting and 'metabolic switch': Effects on metabolic syndrome, prediabetes and type 2 diabetes. Diabetes Obes. Metab. 2020, 22, 1496-1510. [CrossRef] [PubMed]

86. Trepanowski, J.F.; Kroeger, C.M.; Barnosky, A.; Klempel, M.C.; Bhutani, S.; Hoddy, K.K.; Gabel, K.; Freels, S.; Rigdon, J.; Rood, J.; et al. Effect of Alternate-Day Fasting on Weight Loss, Weight Maintenance, and Cardioprotection Among Metabolically Healthy Obese Adults: A Randomized Clinical Trial. JAMA Intern. Med. 2017, 177, 930-938. [CrossRef]

87. Sundfor, T.M.; Svendsen, M.; Tonstad, S. Effect of intermittent versus continuous energy restriction on weight loss, maintenance and cardiometabolic risk: A randomized 1-year trial. Nutr. Metab. Cardiovasc. Dis. 2018, 28, 698-706. [CrossRef]

88. Sutton, E.F.; Beyl, R.; Early, K.S.; Cefalu, W.T.; Ravussin, E.; Peterson, C.M. Early Time-Restricted Feeding Improves Insulin Sensitivity, Blood Pressure, and Oxidative Stress Even without Weight Loss in Men with Prediabetes. Cell. Metab. 2018, 27, 1212-1221.e3. [CrossRef]

89. Corley, B.T.; Carroll, R.W.; Hall, R.M.; Weatherall, M.; Parry-Strong, A.; Krebs, J.D. Intermittent fasting in Type 2 diabetes mellitus and the risk of hypoglycaemia: A randomized controlled trial. Diabet. Med. 2018, 35, 588-594. [CrossRef] [PubMed]

90. Arnason, T.G.; Bowen, M.W.; Mansell, K.D. Effects of intermittent fasting on health markers in those with type 2 diabetes: A pilot study. World J. Diabetes 2017, 8, 154-164. [CrossRef]

91. Carter, S.; Clifton, P.M.; Keogh, J.B. Effect of Intermittent Compared with Continuous Energy Restricted Diet on Glycemic Control in Patients with Type 2 Diabetes: A Randomized Noninferiority Trial. JAMA Netw. Open 2018, 1, e180756. [CrossRef] [PubMed]

92. Ash, S.; Reeves, M.M.; Yeo, S.; Morrison, G.; Carey, D.; Capra, S. Effect of intensive dietetic interventions on weight and glycaemic control in overweight men with Type II diabetes: A randomised trial. Int. J. Obes. Relat. Metab. Disord. 2003, 27, 797-802. [CrossRef]

93. Carter, S.; Clifton, P.M.; Keogh, J.B. The effects of intermittent compared to continuous energy restriction on glycaemic control in type 2 diabetes; a pragmatic pilot trial. Diabetes Res. Clin. Pract. 2016, 122, 106-112. [CrossRef] [PubMed]

94. Moran, M. The evolution of the nutritional management of diabetes. Proc. Nutr. Soc. 2004, 63, 615-620. [CrossRef]

95. Sawyer, L.; Gale, E.A. Diet, delusion and diabetes. Diabetologia 2009, 52, 1-7. [CrossRef] [PubMed]

96. Banting, W. Letter on Corpulence, Addressed to the Public with Addenda; Wiley: Hoboken, NJ, USA, 1869.

97. Dr. Atkin's New Diet Revolution; Quill: Lincolnshire, IL, USA, 2009. 
98. Saslow, L.R.; Daubenmier, J.J.; Moskowitz, J.T.; Kim, S.; Murphy, E.J.; Phinney, S.D.; Ploutz-Snyder, R.; Goldman, V.; Cox, R.M.; Mason, A.E.; et al. Twelve-month outcomes of a randomized trial of a moderate-carbohydrate versus very low-carbohydrate diet in overweight adults with type 2 diabetes mellitus or prediabetes. Nutr. Diabetes 2017, 7, 304-309. [CrossRef]

99. Paoli, A.; Rubini, A.; Volek, J.S.; Grimaldi, K.A. Beyond weight loss: A review of the therapeutic uses of very-low-carbohydrate (ketogenic) diets. Eur. J. Clin. Nutr. 2013, 67, 789-796. [CrossRef]

100. Hallberg, S.J.; McKenzie, A.L.; Williams, P.T.; Bhanpuri, N.H.; Peters, A.L.; Campbell, W.W.; Hazbun, T.L.; Volk, B.M.; McCarter, J.P.; Phinney, S.D.; et al. Effectiveness and Safety of a Novel Care Model for the Management of Type 2 Diabetes at 1 Year: An Open-Label, Non-Randomized, Controlled Study. Diabetes Ther. 2018, 9, 583-612. [CrossRef] [PubMed]

101. Snorgaard, O.; Poulsen, G.M.; Andersen, H.K.; Astrup, A. Systematic review and meta-analysis of dietary carbohydrate restriction in patients with type 2 diabetes. BMJ Open Diabetes Res. Care. 2017, 5, e000354. [CrossRef] [PubMed]

102. Meng, Y.; Bai, H.; Wang, S.; Li, Z.; Wang, Q.; Chen, L. Efficacy of low carbohydrate diet for type 2 diabetes mellitus management: A systematic review and meta-analysis of randomized controlled trials. Diabetes Res. Clin. Pract. 2017, 131, 124-131. [CrossRef]

103. Diabetes Canada Position Statement on Low-Carbohydrate Diets for Adults with Diabetes: A Rapid Review. Can. J. Diabetes 2020, 44, 295-299. [CrossRef]

104. Freire, R. Scientific evidence of diets for weight loss: Different macronutrient composition, intermittent fasting, and popular diets. Nutrition 2020, 69, 110549. [CrossRef]

105. Ross, L.J.; Byrnes, A.; Hay, R.L.; Cawte, A.; Musial, J.E. Exploring the highs and lows of very low carbohydrate high fat diets on weight loss and diabetes- and cardiovascular disease-related risk markers: A systematic review. Nutr. Diet. 2021, 78, 41-56. [CrossRef]

106. Gannon, M.C.; Nuttall, F.Q. Effect of a high-protein, low-carbohydrate diet on blood glucose control in people with type 2 diabetes. Diabetes 2004, 53, 2375-2382. [CrossRef]

107. Dimosthenopoulos, C.; Liatis, S.; Kourpas, E.; Athanasopoulou, E.; Driva, S.; Makrilakis, K.; Kokkinos, A. The beneficial shortterm effects of a high-protein/low-carbohydrate diet on glycaemic control assessed by continuous glucose monitoring in patients with type 1 diabetes. Diabetes Obes. Metab. 2021. [CrossRef] [PubMed]

108. Goldenberg, J.Z.; Day, A.; Brinkworth, G.D.; Sato, J.; Yamada, S.; Jonsson, T.; Beardsley, J.; Johnson, J.A.; Thabane, L.; Johnston, B.C. Efficacy and safety of low and very low carbohydrate diets for type 2 diabetes remission: Systematic review and meta-analysis of published and unpublished randomized trial data. BMJ 2021, 372, m4743. [CrossRef] [PubMed]

109. Silverii, G.A.; Botarelli, L.; Dicembrini, I.; Girolamo, V.; Santagiuliana, F.; Monami, M.; Mannucci, E. Low-carbohydrate diets and type 2 diabetes treatment: A meta-analysis of randomized controlled trials. Acta Diabetol. 2020, 57, 1375-1382. [CrossRef] [PubMed]

110. van Zuuren, E.J.; Fedorowicz, Z.; Kuijpers, T.; Pijl, H. Effects of low-carbohydrate- compared with low-fat-diet interventions on metabolic control in people with type 2 diabetes: A systematic review including GRADE assessments. Am. J. Clin. Nutr. 2018, 108, 300-331. [CrossRef] [PubMed]

111. Westman, E.C.; Yancy, W.S. Using a low-carbohydrate diet to treat obesity and type 2 diabetes mellitus. Curr. Opin. Endocrinol. Diabetes Obes. 2020, 27, 255-260. [CrossRef] [PubMed]

112. Yancy, W.S.; Foy, M.; Chalecki, A.M.; Vernon, M.C.; Westman, E.C. A low-carbohydrate, ketogenic diet to treat type 2 diabetes. Nutr. Metab. 2005, 2, 34. [CrossRef]

113. Tay, J.; Luscombe-Marsh, N.D.; Thompson, C.H.; Noakes, M.; Buckley, J.D.; Wittert, G.A.; Yancy, W.S.; Brinkworth, G.D. Comparison of low- and high-carbohydrate diets for type 2 diabetes management: A randomized trial. Am. J. Clin. Nutr. 2015, 102, 780-790. [CrossRef]

114. Athinarayanan, S.J.; Adams, R.N.; Hallberg, S.J.; McKenzie, A.L.; Bhanpuri, N.H.; Campbell, W.W.; Volek, J.S.; Phinney, S.D.; McCarter, J.P. Long-Term Effects of a Novel Continuous Remote Care Intervention Including Nutritional Ketosis for the Management of Type 2 Diabetes: A 2-Year Non-randomized Clinical Trial. Front. Endocrinol. (Lausanne) 2019, 10, 348. [CrossRef]

115. Foster, G.D.; Wyatt, H.R.; Hill, J.O.; Makris, A.P.; Rosenbaum, D.L.; Brill, C.; Stein, R.I.; Mohammed, B.S.; Miller, B.; Rader, D.J.; et al. Weight and metabolic outcomes after 2 years on a low-carbohydrate versus low-fat diet: A randomized trial. Ann. Intern. Med. 2010, 153, 147-157. [CrossRef]

116. Gardner, C.D.; Trepanowski, J.F.; Del Gobbo, L.C.; Hauser, M.E.; Rigdon, J.; Ioannidis, J.P.A.; Desai, M.; King, A.C. Effect of Low-Fat vs Low-Carbohydrate Diet on 12-Month Weight Loss in Overweight Adults and the Association with Genotype Pattern or Insulin Secretion: The DIETFITS Randomized Clinical Trial. JAMA 2018, 319, 667-679. [CrossRef] [PubMed]

117. Dyson, P. Very low carbohydrate ketogenic diets and diabetes. Pract. Diabetes 2020, 37, 121-126. [CrossRef]

118. Sainsbury, E.; Kizirian, N.V.; Partridge, S.R.; Gill, T.; Colagiuri, S.; Gibson, A.A. Effect of dietary carbohydrate restriction on glycemic control in adults with diabetes: A systematic review and meta-analysis. Diabetes Res. Clin. Pract. 2018, 139, $239-252$. [CrossRef] [PubMed]

119. Goday, A.; Bellido, D.; Sajoux, I.; Crujeiras, A.B.; Burguera, B.; Garcia-Luna, P.P.; Oleaga, A.; Moreno, B.; Casanueva, F.F. Shortterm safety, tolerability and efficacy of a very low-calorie-ketogenic diet interventional weight loss program versus hypocaloric diet in patients with type 2 diabetes mellitus. Nutr. Diabetes 2016, 6, e230. [CrossRef]

120. Hussain, T.A.; Mathew, T.C.; Dashti, A.A.; Asfar, S.; Al-Zaid, N.; Dashti, H.M. Effect of low-calorie versus low-carbohydrate ketogenic diet in type 2 diabetes. Nutrition 2012, 28, 1016-1021. [CrossRef] [PubMed] 
121. Westman, E.C.; Yancy, W.S.; Mavropoulos, J.C.; Marquart, M.; McDuffie, J.R. The effect of a low-carbohydrate, ketogenic diet versus a low-glycemic index diet on glycemic control in type 2 diabetes mellitus. Nutr. Metab. 2008, 5, 36. [CrossRef]

122. Livesey, G.; Taylor, R.; Livesey, H.F.; Buyken, A.E.; Jenkins, D.J.A.; Augustin, L.S.A.; Sievenpiper, J.L.; Barclay, A.W.; Liu, S.; Wolever, T.M.S.; et al. Dietary Glycemic Index and Load and the Risk of Type 2 Diabetes: Assessment of Causal Relations. Nutrients 2019, 11, 1436. [CrossRef]

123. Jenkins, D.J.; Wolever, T.M.; Taylor, R.H.; Barker, H.; Fielden, H.; Baldwin, J.M.; Bowling, A.C.; Newman, H.C.; Jenkins, A.L.; Goff, D.V. Glycemic index of foods: A physiological basis for carbohydrate exchange. Am. J. Clin. Nutr. 1981, 34, 362-366. [CrossRef]

124. Shahdadian, F.; Saneei, P.; Milajerdi, A.; Esmaillzadeh, A. Dietary glycemic index, glycemic load, and risk of mortality from all causes and cardiovascular diseases: A systematic review and dose-response meta-analysis of prospective cohort studies. Am. J. Clin. Nutr. 2019, 110, 921-937. [CrossRef]

125. Canadian Diabetes Association Clinical Practice Guidelines Expert Committee; Cheng, A.Y.L.A. Canadian Diabetes Association 2013 clinical practice guidelines for the prevention and management of diabetes in Canada. Introduction. Can. J. Diabetes 2013, 37 (Suppl. 1), 1. [CrossRef]

126. Larsen, T.M.; Dalskov, S.M.; van Baak, M.; Jebb, S.A.; Papadaki, A.; Pfeiffer, A.F.; Martinez, J.A.; Handjieva-Darlenska, T.; Kunesova, M.; Pihlsgard, M.; et al. Diets with high or low protein content and glycemic index for weight-loss maintenance. $N$. Engl. J. Med. 2010, 363, 2102-2113. [CrossRef]

127. Livesey, G.; Taylor, R.; Livesey, H.F.; Buyken, A.E.; Jenkins, D.J.A.; Augustin, L.S.A.; Sievenpiper, J.L.; Barclay, A.W.; Liu, S.; Wolever, T.M.S.; et al. Dietary Glycemic Index and Load and the Risk of Type 2 Diabetes: A Systematic Review and Updated Meta-Analyses of Prospective Cohort Studies. Nutrients 2019, 11, 1280. [CrossRef]

128. Bhupathiraju, S.N.; Tobias, D.K.; Malik, V.S.; Pan, A.; Hruby, A.; Manson, J.E.; Willett, W.C.; Hu, F.B. Glycemic index, glycemic load, and risk of type 2 diabetes: Results from 3 large US cohorts and an updated meta-analysis. Am. J. Clin. Nutr. 2014, 100, 218-232. [CrossRef]

129. Brand-Miller, J.; Hayne, S.; Petocz, P.; Colagiuri, S. Low-glycemic index diets in the management of diabetes: A meta-analysis of randomized controlled trials. Diabetes Care 2003, 26, 2261-2267. [CrossRef]

130. Zafar, M.I.; Mills, K.E.; Zheng, J.; Regmi, A.; Hu, S.Q.; Gou, L.; Chen, L.L. Low-glycemic index diets as an intervention for diabetes: A systematic review and meta-analysis. Am. J. Clin. Nutr. 2019, 110, 891-902. [CrossRef] [PubMed]

131. Ojo, O.; Ojo, O.O.; Wang, X.H.; Adegboye, A.R.A. The Effects of a Low GI Diet on Cardiometabolic and Inflammatory Parameters in Patients with Type 2 and Gestational Diabetes: A Systematic Review and Meta-Analysis of Randomised Controlled Trials. Nutrients 2019, 11, 1584. [CrossRef]

132. Wang, Q.; Xia, W.; Zhao, Z.; Zhang, H. Effects comparison between low glycemic index diets and high glycemic index diets on $\mathrm{HbA1c}$ and fructosamine for patients with diabetes: A systematic review and meta-analysis. Prim. Care. Diabetes 2015, 9, 362-369. [CrossRef]

133. Wang, M.L.; Gellar, L.; Nathanson, B.H.; Pbert, L.; Ma, Y.; Ockene, I.; Rosal, M.C. Decrease in Glycemic Index Associated with Improved Glycemic Control among Latinos with Type 2 Diabetes. J. Acad. Nutr. Diet. 2015, 115, 898-906. [CrossRef] [PubMed]

134. Gomes, J.M.G.; Fabrini, S.P.; Alfenas, R.C.G. Low glycemic index diet reduces body fat and attenuates inflammatory and metabolic responses in patients with type 2 diabetes. Arch. Endocrinol. Metab. 2017, 61, 137-144. [CrossRef]

135. Jenkins, D.J.; Kendall, C.W.; McKeown-Eyssen, G.; Josse, R.G.; Silverberg, J.; Booth, G.L.; Vidgen, E.; Josse, A.R.; Nguyen, T.H.; Corrigan, S.; et al. Effect of a low-glycemic index or a high-cereal fiber diet on type 2 diabetes: A randomized trial. JAMA 2008, 300, 2742-2753. [CrossRef] [PubMed]

136. Wolever, T.M.; Mehling, C.; Chiasson, J.L.; Josse, R.G.; Leiter, L.A.; Maheux, P.; Rabasa-Lhoret, R.; Rodger, N.W.; Ryan, E.A. Low glycaemic index diet and disposition index in type 2 diabetes (the Canadian trial of carbohydrates in diabetes): A randomised controlled trial. Diabetologia 2008, 51, 1607-1615. [CrossRef] [PubMed]

137. DeFronzo, R.A.; Ferrannini, E. Regulation of hepatic glucose metabolism in humans. Diabetes Metab. Rev. 1987, 3, 415-459. [CrossRef] [PubMed]

138. Srikanthan, P.; Karlamangla, A.S. Relative muscle mass is inversely associated with insulin resistance and prediabetes. Findings from the third National Health and Nutrition Examination Survey. J. Clin. Endocrinol. Metab. 2011, 96, 2898-2903. [CrossRef] [PubMed]

139. Cleasby, M.E.; Jarmin, S.; Eilers, W.; Elashry, M.; Andersen, D.K.; Dickson, G.; Foster, K. Local overexpression of the myostatin propeptide increases glucose transporter expression and enhances skeletal muscle glucose disposal. Am. J. Physiol. Endocrinol. Metab. 2014, 306, 814. [CrossRef]

140. Holten, M.K.; Zacho, M.; Gaster, M.; Juel, C.; Wojtaszewski, J.F.; Dela, F. Strength training increases insulin-mediated glucose uptake, GLUT4 content, and insulin signaling in skeletal muscle in patients with type 2 diabetes. Diabetes 2004, 53, 294-305. [CrossRef]

141. Amor, M.; Itariu, B.K.; Moreno-Viedma, V.; Keindl, M.; Jurets, A.; Prager, G.; Langer, F.; Grablowitz, V.; Zeyda, M.; Stulnig, T.M. Serum Myostatin is Upregulated in Obesity and Correlates with Insulin Resistance in Humans. Exp. Clin. Endocrinol. Diabetes 2019, 127, 550-556. [CrossRef]

142. Shabkhiz, F.; Khalafi, M.; Rosenkranz, S.; Karimi, P.; Moghadami, K. Resistance training attenuates circulating FGF-21 and myostatin and improves insulin resistance in elderly men with and without type 2 diabetes mellitus: A randomised controlled clinical trial. Eur. J. Sport. Sci. 2021, 21, 636-645. [CrossRef] 
143. Alhazmi, A.; Stojanovski, E.; McEvoy, M.; Garg, M.L. Macronutrient intake and type 2 diabetes risk in middle-aged Australian women. Results from the Australian Longitudinal Study on Women's Health. Public Health Nutr. 2014, 17, 1587-1594. [CrossRef]

144. Smeuninx, B.; Mckendry, J.; Wilson, D.; Martin, U.; Breen, L. Age-Related Anabolic Resistance of Myofibrillar Protein Synthesis Is Exacerbated in Obese Inactive Individuals. J. Clin. Endocrinol. Metab. 2017, 102, 3535-3545. [CrossRef]

145. Kouw, I.W.; Gorissen, S.H.; Burd, N.A.; Cermak, N.M.; Gijsen, A.P.; van Kranenburg, J.; van Loon, L.J. Postprandial Protein Handling Is Not Impaired in Type 2 Diabetes Patients When Compared with Normoglycemic Controls. J. Clin. Endocrinol. Metab. 2015, 100, 3103-3111. [CrossRef]

146. Yang, Y.; Breen, L.; Burd, N.A.; Hector, A.J.; Churchward-Venne, T.A.; Josse, A.R.; Tarnopolsky, M.A.; Phillips, S.M. Resistance exercise enhances myofibrillar protein synthesis with graded intakes of whey protein in older men. Br. J. Nutr. 2012, 108, 1780-1788. [CrossRef]

147. Shad, B.J.; Thompson, J.L.; Breen, L. Does the muscle protein synthetic response to exercise and amino acid-based nutrition diminish with advancing age? A systematic review. Am. J. Physiol. Endocrinol. Metab. 2016, 311, E803-E817. [CrossRef] [PubMed]

148. Moore, D.R.; Churchward-Venne, T.A.; Witard, O.; Breen, L.; Burd, N.A.; Tipton, K.D.; Phillips, S.M. Protein ingestion to stimulate myofibrillar protein synthesis requires greater relative protein intakes in healthy older versus younger men. J. Gerontol. A Biol. Sci. Med. Sci. 2015, 70, 57-62. [CrossRef]

149. Cuthbertson, D.; Smith, K.; Babraj, J.; Leese, G.; Waddell, T.; Atherton, P.; Wackerhage, H.; Taylor, P.M.; Rennie, M.J. Anabolic signaling deficits underlie amino acid resistance of wasting, aging muscle. FASEB J. 2005, 19, 422-424. [CrossRef] [PubMed]

150. Bauer, J.; Biolo, G.; Cederholm, T.; Cesari, M.; Cruz-Jentoft, A.J.; Morley, J.E.; Phillips, S.; Sieber, C.; Stehle, P.; Teta, D.; et al. Evidence-based recommendations for optimal dietary protein intake in older people: A position paper from the PROT-AGE Study Group. J. Am. Med. Dir. Assoc. 2013, 14, 542-559. [CrossRef] [PubMed]

151. Marshall, R.N.; Smeuninx, B.; Morgan, P.T.; Breen, L. Nutritional Strategies to Offset Disuse-Induced Skeletal Muscle Atrophy and Anabolic Resistance in Older Adults: From Whole-Foods to Isolated Ingredients. Nutrients 2020, 12, 1533. [CrossRef] [PubMed]

152. Hamdy, O.; Horton, E.S. Protein content in diabetes nutrition plan. Curr. Diab Rep. 2011, 11, 111-119. [CrossRef]

153. Heymsfield, S.B.; Gallagher, D.; Kotler, D.P.; Wang, Z.; Allison, D.B.; Heshka, S. Body-size dependence of resting energy expenditure can be attributed to nonenergetic homogeneity of fat-free mass. Am. J. Physiol. Endocrinol. Metab. 2002, $282,132$. [CrossRef]

154. Muller, M.J.; Bosy-Westphal, A.; Kutzner, D.; Heller, M. Metabolically active components of fat-free mass and resting energy expenditure in humans: Recent lessons from imaging technologies. Obes. Rev. 2002, 3, 113-122. [CrossRef]

155. McMurray, R.G.; Soares, J.; Caspersen, C.J.; McCurdy, T. Examining variations of resting metabolic rate of adults: A public health perspective. Med. Sci. Sports Exerc. 2014, 46, 1352-1358. [CrossRef]

156. Bal, N.C.; Maurya, S.K.; Sopariwala, D.H.; Sahoo, S.K.; Gupta, S.C.; Shaikh, S.A.; Pant, M.; Rowland, L.A.; Bombardier, E.; Goonasekera, S.A.; et al. Sarcolipin is a newly identified regulator of muscle-based thermogenesis in mammals. Nat. Med. 2012, 18, 1575-1579. [CrossRef] [PubMed]

157. Mikkelsen, P.B.; Toubro, S.; Astrup, A. Effect of fat-reduced diets on 24-h energy expenditure: Comparisons between animal protein, vegetable protein, and carbohydrate. Am. J. Clin. Nutr. 2000, 72, 1135-1141. [CrossRef]

158. Gavini, C.K.; Mukherjee, S.; Shukla, C.; Britton, S.L.; Koch, L.G.; Shi, H.; Novak, C.M. Leanness and heightened nonresting energy expenditure: Role of skeletal muscle activity thermogenesis. Am. J. Physiol. Endocrinol. Metab. 2014, 306, 635. [CrossRef]

159. Drummen, M.; Tischmann, L.; Gatta-Cherifi, B.; Fogelholm, M.; Raben, A.; Adam, T.C.; Westerterp-Plantenga, M.S. High Compared with Moderate Protein Intake Reduces Adaptive Thermogenesis and Induces a Negative Energy Balance during Long-term Weight-Loss Maintenance in Participants with Prediabetes in the Postobese State: A PREVIEW Study. J. Nutr. 2020, 150, 458-463. [CrossRef]

160. Soenen, S.; Martens, E.A.; Hochstenbach-Waelen, A.; Lemmens, S.G.; Westerterp-Plantenga, M.S. Normal protein intake is required for body weight loss and weight maintenance, and elevated protein intake for additional preservation of resting energy expenditure and fat free mass. J. Nutr. 2013, 143, 591-596. [CrossRef] [PubMed]

161. Horiuchi, M.; Takeda, T.; Takanashi, H.; Ozaki-Masuzawa, Y.; Taguchi, Y.; Toyoshima, Y.; Otani, L.; Kato, H.; Sone-Yonezawa, M.; Hakuno, F.; et al. Branched-chain amino acid supplementation restores reduced insulinotropic activity of a low-protein diet through the vagus nerve in rats. Nutr. Metab. 2017, 14, 59. [CrossRef]

162. Pal, S.; Ellis, V. The acute effects of four protein meals on insulin, glucose, appetite and energy intake in lean men. Br. J. Nutr. 2010, 104, 1241-1248. [CrossRef]

163. Jakubowicz, D.; Froy, O.; Ahren, B.; Boaz, M.; Landau, Z.; Bar-Dayan, Y.; Ganz, T.; Barnea, M.; Wainstein, J. Incretin, insulinotropic and glucose-lowering effects of whey protein pre-load in type 2 diabetes: A randomised clinical trial. Diabetologia 2014, 57, 1807-1811. [CrossRef] [PubMed]

164. King, D.G.; Walker, M.; Campbell, M.D.; Breen, L.; Stevenson, E.J.; West, D.J. A small dose of whey protein co-ingested with mixed-macronutrient breakfast and lunch meals improves postprandial glycemia and suppresses appetite in men with type 2 diabetes: A randomized controlled trial. Am. J. Clin. Nutr. 2018, 107, 550-557. [CrossRef]

165. Pal, S.; Ellis, V.; Dhaliwal, S. Effects of whey protein isolate on body composition, lipids, insulin and glucose in overweight and obese individuals. Br. J. Nutr. 2010, 104, 716-723. [CrossRef] [PubMed] 
166. Weickert, M.O.; Roden, M.; Isken, F.; Hoffmann, D.; Nowotny, P.; Osterhoff, M.; Blaut, M.; Alpert, C.; Gogebakan, O.; Bumke-Vogt, C.; et al. Effects of supplemented isoenergetic diets differing in cereal fiber and protein content on insulin sensitivity in overweight humans. Am. J. Clin. Nutr. 2011, 94, 459-471. [CrossRef]

167. Leenders, M.; Verdijk, L.B.; van der Hoeven, L.; van Kranenburg, J.; Hartgens, F.; Wodzig, W.K.; Saris, W.H.; van Loon, L.J. Prolonged leucine supplementation does not augment muscle mass or affect glycemic control in elderly type 2 diabetic men. $J$. Nutr. 2011, 141, 1070-1076. [CrossRef]

168. Karusheva, Y.; Koessler, T.; Strassburger, K.; Markgraf, D.; Mastrototaro, L.; Jelenik, T.; Simon, M.C.; Pesta, D.; Zaharia, O.P.; Bodis, K.; et al. Short-term dietary reduction of branched-chain amino acids reduces meal-induced insulin secretion and modifies microbiome composition in type 2 diabetes: A randomized controlled crossover trial. Am. J. Clin. Nutr. 2019, 110, 1098-1107. [CrossRef] [PubMed]

169. Corpeleijn, E.; Saris, W.H.; Blaak, E.E. Metabolic flexibility in the development of insulin resistance and type 2 diabetes: Effects of lifestyle. Obes. Rev. 2009, 10, 178-193. [CrossRef] [PubMed]

170. Sargrad, K.R.; Homko, C.; Mozzoli, M.; Boden, G. Effect of high protein vs high carbohydrate intake on insulin sensitivity, body weight, hemoglobin A1c, and blood pressure in patients with type 2 diabetes mellitus. J. Am. Diet. Assoc. 2005, 105, 573-580. [CrossRef]

171. Gannon, M.C.; Nuttall, F.Q.; Saeed, A.; Jordan, K.; Hoover, H. An increase in dietary protein improves the blood glucose response in persons with type 2 diabetes. Am. J. Clin. Nutr. 2003, 78, 734-741. [CrossRef]

172. Yu, D.; Richardson, N.E.; Green, C.L.; Spicer, A.B.; Murphy, M.E.; Flores, V.; Jang, C.; Kasza, I.; Nikodemova, M.; Wakai, M.H.; et al. The adverse metabolic effects of branched-chain amino acids are mediated by isoleucine and valine. Cell. Metab. 2021, 33, 905-922.e6. [CrossRef] [PubMed]

173. Gorissen, S.H.M.; Crombag, J.J.R.; Senden, J.M.G.; Waterval, W.A.H.; Bierau, J.; Verdijk, L.B.; van Loon, L.J.C. Protein content and amino acid composition of commercially available plant-based protein isolates. Amino Acids 2018, 50, 1685-1695. [CrossRef] [PubMed]

174. Kahleova, H.; Tura, A.; Klementova, M.; Thieme, L.; Haluzik, M.; Pavlovicova, R.; Hill, M.; Pelikanova, T. A Plant-Based Meal Stimulates Incretin and Insulin Secretion More Than an Energy- and Macronutrient-Matched Standard Meal in Type 2 Diabetes: A Randomized Crossover Study. Nutrients 2019, 11, 486. [CrossRef]

175. Wheeler, M.L.; Fineberg, S.E.; Fineberg, N.S.; Gibson, R.G.; Hackward, L.L. Animal versus plant protein meals in individuals with type 2 diabetes and microalbuminuria: Effects on renal, glycemic, and lipid parameters. Diabetes Care 2002, 25, 1277-1282. [CrossRef] [PubMed]

176. Viguiliouk, E.; Stewart, S.E.; Jayalath, V.H.; Ng, A.P.; Mirrahimi, A.; de Souza, R.J.; Hanley, A.J.; Bazinet, R.P.; Blanco Mejia, S.; Leiter, L.A.; et al. Effect of Replacing Animal Protein with Plant Protein on Glycemic Control in Diabetes: A Systematic Review and Meta-Analysis of Randomized Controlled Trials. Nutrients 2015, 7, 9804-9824. [CrossRef] [PubMed]

177. Krook, A.; Bjornholm, M.; Galuska, D.; Jiang, X.J.; Fahlman, R.; Myers, M.G.; Wallberg-Henriksson, H.; Zierath, J.R. Characterization of signal transduction and glucose transport in skeletal muscle from type 2 diabetic patients. Diabetes 2000, 49, 284-292. [CrossRef] [PubMed]

178. Perreault, L.; Newsom, S.A.; Strauss, A.; Kerege, A.; Kahn, D.E.; Harrison, K.A.; Snell-Bergeon, J.K.; Nemkov, T.; D’Alessandro, A.; Jackman, M.R.; et al. Intracellular localization of diacylglycerols and sphingolipids influences insulin sensitivity and mitochondrial function in human skeletal muscle. JCI Insight 2018, 3. [CrossRef] [PubMed]

179. Bell, J.A.; Reed, M.A.; Consitt, L.A.; Martin, O.J.; Haynie, K.R.; Hulver, M.W.; Muoio, D.M.; Dohm, G.L. Lipid partitioning, incomplete fatty acid oxidation, and insulin signal transduction in primary human muscle cells: Effects of severe obesity, fatty acid incubation, and fatty acid translocase/CD36 overexpression. J. Clin. Endocrinol. Metab. 2010, 95, 3400-3410. [CrossRef]

180. Batterham, R.L.; Cohen, M.A.; Ellis, S.M.; Le Roux, C.W.; Withers, D.J.; Frost, G.S.; Ghatei, M.A.; Bloom, S.R. Inhibition of food intake in obese subjects by peptide YY3-36. N. Engl. J. Med. 2003, 349, 941-948. [CrossRef]

181. Sloth, B.; Holst, J.J.; Flint, A.; Gregersen, N.T.; Astrup, A. Effects of PYY1-36 and PYY3-36 on appetite, energy intake, energy expenditure, glucose and fat metabolism in obese and lean subjects. Am. J. Physiol. Endocrinol. Metab. 2007, 292, 1062. [CrossRef]

182. Toft-Nielsen, M.B.; Madsbad, S.; Holst, J.J. Continuous subcutaneous infusion of glucagon-like peptide 1 lowers plasma glucose and reduces appetite in type 2 diabetic patients. Diabetes Care 1999, 22, 1137-1143. [CrossRef]

183. Hagemann, D.; Holst, J.J.; Gethmann, A.; Banasch, M.; Schmidt, W.E.; Meier, J.J. Glucagon-like peptide 1 (GLP-1) suppresses ghrelin levels in humans via increased insulin secretion. Regul. Pept. 2007, 143, 64-68. [CrossRef]

184. Ingves, S.; Vilhelmsson, N.; Strom, E.; Fredrikson, M.; Guldbrand, H.; Nystrom, F.H. A randomized cross-over study of the effects of macronutrient composition and meal frequency on GLP-1, ghrelin and energy expenditure in humans. Peptides 2017, 93, 20-26. [CrossRef]

185. Parvaresh Rizi, E.; Loh, T.P.; Baig, S.; Chhay, V.; Huang, S.; Caleb Quek, J.; Tai, E.S.; Toh, S.A.; Khoo, C.M. A high carbohydrate, but not fat or protein meal attenuates postprandial ghrelin, PYY and GLP-1 responses in Chinese men. PLoS ONE 2018, 13, e0191609. [CrossRef]

186. Batterham, R.L.; Heffron, H.; Kapoor, S.; Chivers, J.E.; Chandarana, K.; Herzog, H.; Le Roux, C.W.; Thomas, E.L.; Bell, J.D.; Withers, D.J. Critical role for peptide YY in protein-mediated satiation and body-weight regulation. Cell. Metab. 2006, 4, $223-233$. [CrossRef] 
187. Brennan, I.M.; Luscombe-Marsh, N.D.; Seimon, R.V.; Otto, B.; Horowitz, M.; Wishart, J.M.; Feinle-Bisset, C. Effects of fat, protein, and carbohydrate and protein load on appetite, plasma cholecystokinin, peptide $Y Y$, and ghrelin, and energy intake in lean and obese men. Am. J. Physiol. Gastrointest. Liver Physiol. 2012, 303, 129. [CrossRef]

188. Pal, S.; Radavelli-Bagatini, S.; Hagger, M.; Ellis, V. Comparative effects of whey and casein proteins on satiety in overweight and obese individuals: A randomized controlled trial. Eur. J. Clin. Nutr. 2014, 68, 980-986. [CrossRef]

189. Oberoi, A.; Giezenaar, C.; Jensen, C.; Lange, K.; Hausken, T.; Jones, K.L.; Horowitz, M.; Chapman, I.; Soenen, S. Acute effects of whey protein on energy intake, appetite and gastric emptying in younger and older, obese men. Nutr. Diabetes 2020, 10, 37-38. [CrossRef]

190. Hall, W.L.; Millward, D.J.; Long, S.J.; Morgan, L.M. Casein and whey exert different effects on plasma amino acid profiles, gastrointestinal hormone secretion and appetite. Br. J. Nutr. 2003, 89, 239-248. [CrossRef]

191. Geraedts, M.C.; Troost, F.J.; Fischer, M.A.; Edens, L.; Saris, W.H. Direct induction of CCK and GLP-1 release from murine endocrine cells by intact dietary proteins. Mol. Nutr. Food Res. 2011, 55, 476-484. [CrossRef]

192. Kato, M.; Nakanishi, T.; Tani, T.; Tsuda, T. Low-molecular fraction of wheat protein hydrolysate stimulates glucagon-like peptide-1 secretion in an enteroendocrine $\mathrm{L}$ cell line and improves glucose tolerance in rats. Nutr. Res. 2017, 37, 37-45. [CrossRef]

193. Ghazzawi, H.A.; Mustafa, S. Effect of high-protein breakfast meal on within-day appetite hormones: Peptide YY, glucagon like peptide-1 in adults. Clin. Nutr. Exp. 2019, 28, 111-122. [CrossRef]

194. Leidy, H.J.; Tang, M.; Armstrong, C.L.; Martin, C.B.; Campbell, W.W. The effects of consuming frequent, higher protein meals on appetite and satiety during weight loss in overweight/obese men. Obesity 2011, 19, 818-824. [CrossRef] [PubMed]

195. Kondrashina, A.; Brodkorb, A.; Giblin, L. Dairy-derived peptides for satiety. J. Funct. Foods 2020, 66, 103801. [CrossRef]

196. Goyenechea, E.; Holst, C.; van Baak, M.A.; Saris, W.H.; Jebb, S.; Kafatos, A.; Pfeiffer, A.; Handjiev, S.; Hlavaty, P.; Stender, S.; et al. DIOGenes Effects of different protein content and glycaemic index of ad libitum diets on diabetes risk factors in overweight adults: The DIOGenes multicentre, randomized, dietary intervention trial. Diabetes Metab. Res. Rev. 2011, 27, 705-716. [CrossRef]

197. Astrup, A.; Raben, A.; Geiker, N. The role of higher protein diets in weight control and obesity-related comorbidities. Int. J. Obes. 2015, 39, 721-726. [CrossRef]

198. Chen, X.; Yang, W. Branched-chain amino acids and the association with type 2 diabetes. J. Diabetes Investig. 2015, 6, 369-370. [CrossRef]

199. Holecek, M. Branched-chain amino acids in health and disease: Metabolism, alterations in blood plasma, and as supplements. Nutr. Metab. 2018, 15, 33. [CrossRef]

200. Holecek, M. Why Are Branched-Chain Amino Acids Increased in Starvation and Diabetes? Nutrients 2020, 12, 3087. [CrossRef] [PubMed]

201. Mesinovic, J.; Zengin, A.; De Courten, B.; Ebeling, P.R.; Scott, D. Sarcopenia and type 2 diabetes mellitus: A bidirectional relationship. Diabetes Metab. Syndr. Obes. 2019, 12, 1057-1072. [CrossRef] [PubMed]

202. Maykish, A.; Sikalidis, A.K. Utilization of Hydroxyl-Methyl Butyrate, Leucine, Glutamine and Arginine Supplementation in Nutritional Management of Sarcopenia-Implications and Clinical Considerations for Type 2 Diabetes Mellitus Risk Modulation. J. Pers. Med. 2020, 10, 19. [CrossRef] [PubMed]

203. Gojda, J.; Strakova, R.; Plihalova, A.; Tuma, P.; Potockova, J.; Polak, J.; Andel, M. Increased Incretin But Not Insulin Response after Oral versus Intravenous Branched Chain Amino Acids. Ann. Nutr. Metab. 2017, 70, 293-302. [CrossRef] [PubMed]

204. Holst, J.J.; Orskov, C. The incretin approach for diabetes treatment: Modulation of islet hormone release by GLP-1 agonism. Diabetes 2004, 53 (Suppl. 3), 197. [CrossRef] [PubMed]

205. Seino, Y.; Fukushima, M.; Yabe, D. GIP and GLP-1, the two incretin hormones: Similarities and differences. J. Diabetes Investig. 2010, 1, 8-23. [CrossRef]

206. Comerford, K.B.; Pasin, G. Emerging Evidence for the Importance of Dietary Protein Source on Glucoregulatory Markers and Type 2 Diabetes: Different Effects of Dairy, Meat, Fish, Egg, and Plant Protein Foods. Nutrients 2016, 8, 446. [CrossRef]

207. Nicastro, H.; Artioli, G.G.; Costa Ados, S.; Solis, M.Y.; da Luz, C.R.; Blachier, F.; Lancha, A.H. An overview of the therapeutic effects of leucine supplementation on skeletal muscle under atrophic conditions. Amino Acids 2011, 40, 287-300. [CrossRef]

208. Pedroso, J.A.; Zampieri, T.T.; Donato, J. Reviewing the Effects of L-Leucine Supplementation in the Regulation of Food Intake, Energy Balance, and Glucose Homeostasis. Nutrients 2015, 7, 3914-3937. [CrossRef] [PubMed]

209. Zhang, L.; Li, F.; Guo, Q.; Duan, Y.; Wang, W.; Zhong, Y.; Yang, Y.; Yin, Y. Leucine Supplementation: A Novel Strategy for Modulating Lipid Metabolism and Energy Homeostasis. Nutrients 2020, 12, 1299. [CrossRef] [PubMed]

210. Li, F.; Yin, Y.; Tan, B.; Kong, X.; Wu, G. Leucine nutrition in animals and humans: mTOR signaling and beyond. Amino Acids 2011, 41, 1185-1193. [CrossRef]

211. Neinast, M.; Murashige, D.; Arany, Z. Branched Chain Amino Acids. Annu. Rev. Physiol. 2019, 81, 139-164. [CrossRef]

212. Ardestani, A.; Lupse, B.; Kido, Y.; Leibowitz, G.; Maedler, K. mTORC1 Signaling: A Double-Edged Sword in Diabetic beta Cells. Cell. Metab. 2018, 27, 314-331. [CrossRef]

213. Yang, J.; Chi, Y.; Burkhardt, B.R.; Guan, Y.; Wolf, B.A. Leucine metabolism in regulation of insulin secretion from pancreatic beta cells. Nutr. Rev. 2010, 68, 270-279. [CrossRef]

214. Greiwe, J.S.; Kwon, G.; McDaniel, M.L.; Semenkovich, C.F. Leucine and insulin activate p70 S6 kinase through different pathways in human skeletal muscle. Am. J. Physiol. Endocrinol. Metab. 2001, 281, 466. [CrossRef] 
215. Liu, Z.; Long, W.; Fryburg, D.A.; Barrett, E.J. The regulation of body and skeletal muscle protein metabolism by hormones and amino acids. J. Nutr. 2006, 136, 212S-217S. [CrossRef]

216. Candow, D.G.; Forbes, S.C.; Kirk, B.; Duque, G. Current Evidence and Possible Future Applications of Creatine Supplementation for Older Adults. Nutrients 2021, 13, 745. [CrossRef]

217. Candow, D.G.; Chilibeck, P.D.; Forbes, S.C. Creatine supplementation and aging musculoskeletal health. Endocrine 2014, 45, 354-361. [CrossRef] [PubMed]

218. Chilibeck, P.D.; Kaviani, M.; Candow, D.G.; Zello, G.A. Effect of creatine supplementation during resistance training on lean tissue mass and muscular strength in older adults: A meta-analysis. Open Access J. Sports Med. 2017, 8, 213-226. [CrossRef] [PubMed]

219. Devries, M.C.; Phillips, S.M. Creatine supplementation during resistance training in older adults-a meta-analysis. Med. Sci. Sports Exerc. 2014, 46, 1194-1203. [CrossRef]

220. Forbes, S.C.; Candow, D.G.; Ferreira, L.H.B.; Souza-Junior, T.P. Effects of Creatine Supplementation on Properties of Muscle, Bone, and Brain Function in Older Adults: A Narrative Review. J. Diet. Suppl. 2021, 1-18. [CrossRef]

221. Solis, M.Y.; Artioli, G.G.; Gualano, B. Potential of Creatine in Glucose Management and Diabetes. Nutrients 2021, $13,570$. [CrossRef] [PubMed]

222. Wyss, M.; Kaddurah-Daouk, R. Creatine and creatinine metabolism. Physiol. Rev. 2000, 80, 1107-1213. [CrossRef] [PubMed]

223. Jung, S.; Bae, Y.S.; Kim, H.J.; Jayasena, D.D.; Lee, D.D.; Park, H.B.; Heo, K.N.; Jo, C. Carnosine, anserine, creatine, and inosine $5^{\prime}$-monophosphate contents in breast and thigh meats from 5 lines of Korean native chicken. Poult. Sci. 2013, 92, 3275-3282. [CrossRef] [PubMed]

224. Ostojic, S.M.; Korovljev, D.; Stajer, V. Dietary creatine and cognitive function in U.S. adults aged 60 years and over. Aging Clin. Exp. Res. 2021. [CrossRef]

225. Candow, D.G.; Forbes, S.C.; Chilibeck, P.D.; Cornish, S.M.; Antonio, J.; Kreider, R.B. Effectiveness of Creatine Supplementation on Aging Muscle and Bone: Focus on Falls Prevention and Inflammation. J. Clin. Med. 2019, 8, 488. [CrossRef]

226. Harris, R.C.; Soderlund, K.; Hultman, E. Elevation of creatine in resting and exercised muscle of normal subjects by creatine supplementation. Clin. Sci. 1992, 83, 367-374. [CrossRef]

227. Hultman, E.; Soderlund, K.; Timmons, J.A.; Cederblad, G.; Greenhaff, P.L. Muscle creatine loading in men. J. Appl. Physiol. (1985) 1996, 81, 232-237. [CrossRef] [PubMed]

228. Candow, D.G.; Forbes, S.C.; Chilibeck, P.D.; Cornish, S.M.; Antonio, J.; Kreider, R.B. Variables Influencing the Effectiveness of Creatine Supplementation as a Therapeutic Intervention for Sarcopenia. Front. Nutr. 2019, 6, 124. [CrossRef]

229. Forbes, S.C.; Candow, D.G.; Krentz, J.R.; Roberts, M.D.; Young, K.C. Changes in Fat Mass Following Creatine Supplementation and Resistance Training in Adults $>/=50$ Years of Age: A Meta-Analysis. J. Funct. Morphol. Kinesiol. 2019, 4, 62. [CrossRef] [PubMed]

230. Kazak, L.; Chouchani, E.T.; Lu, G.Z.; Jedrychows, P.; Bare, C.J.; Mina, A.I.; Kumari, M.; Zhang, S.; Vuckovic, I.; Laznik-Bogoslavski, D.; et al. Genetic Depletion of Adipocyte Creatine Metabolism Inhibits Diet-Induced Thermogenesis and Drives Obesity. Cell. Metab. 2017, 26, 693. [CrossRef]

231. Kazak, L.; Rahbani, J.F.; Samborska, B.; Lu, G.Z.; Jedrychowski, M.P.; Lajoie, M.; Zhang, S.; Ramsay, L.C.; Dou, F.Y.; Tenen, D.; et al. Ablation of adipocyte creatine transport impairs thermogenesis and causes diet-induced obesity. Nat. Metab. 2019, 1, 360-370. [CrossRef]

232. Ju, J.S.; Smith, J.L.; Oppelt, P.J.; Fisher, J.S. Creatine feeding increases GLUT4 expression in rat skeletal muscle. Am. J. Physiol. Endocrinol. Metab. 2005, 288, 347. [CrossRef] [PubMed]

233. van Loon, L.J.; Murphy, R.; Oosterlaar, A.M.; Cameron-Smith, D.; Hargreaves, M.; Wagenmakers, A.J.; Snow, R. Creatine supplementation increases glycogen storage but not GLUT-4 expression in human skeletal muscle. Clin. Sci. 2004, 106, 99-106. [CrossRef]

234. Rocic, B.; Bajuk, N.B.; Rocic, P.; Weber, D.S.; Boras, J.; Lovrencic, M.V. Comparison of antihyperglycemic effects of creatine and metformin in type II diabetic patients. Clin. Investig. Med. 2009, 32, E322. [CrossRef]

235. Alves, C.R.; Ferreira, J.C.; de Siqueira-Filho, M.A.; Carvalho, C.R.; Lancha, A.H.; Gualano, B. Creatine-induced glucose uptake in type 2 diabetes: A role for AMPK-alpha? Amino Acids 2012, 43, 1803-1807. [CrossRef]

236. Gualano, B.; DE Salles Painneli, V.; Roschel, H.; Artioli, G.G.; Neves, M.; De Sa Pinto, A.L.; Da Silva, M.E.; Cunha, M.R.; Otaduy, M.C.; Leite Cda, C.; et al. Creatine in type 2 diabetes: A randomized, double-blind, placebo-controlled trial. Med. Sci. Sports Exerc. 2011, 43, 770-778. [CrossRef]

237. Gualano, B.; de Salles Painelli, V.; Roschel, H.; Lugaresi, R.; Dorea, E.; Artioli, G.G.; Lima, F.R.; da Silva, M.E.; Cunha, M.R.; Seguro, A.C.; et al. Creatine supplementation does not impair kidney function in type 2 diabetic patients: A randomized, double-blind, placebo-controlled, clinical trial. Eur. J. Appl. Physiol. 2011, 111, 749-756. [CrossRef] [PubMed]

238. Krul-Poel, Y.H.; Ter Wee, M.M.; Lips, P.; Simsek, S. Management of Endocrine Disease: The effect of vitamin D supplementation on glycaemic control in patients with type 2 diabetes mellitus: A systematic review and meta-analysis. Eur. J. Endocrinol. 2017, 176, R1-R14. [CrossRef] [PubMed]

239. Vanchinathan, V.; Lim, H.W. A dermatologist's perspective on vitamin D. Mayo Clin. Proc. 2012, 87, 372-380. [CrossRef] [PubMed]

240. Braun, A.B.; Gibbons, F.K.; Litonjua, A.A.; Giovannucci, E.; Christopher, K.B. Low serum 25-hydroxyvitamin D at critical care initiation is associated with increased mortality. Crit. Care Med. 2012, 40, 63-72. [CrossRef] [PubMed] 
241. Munoz-Garach, A.; Garcia-Fontana, B.; Munoz-Torres, M. Vitamin D Status, Calcium Intake and Risk of Developing Type 2 Diabetes: An Unresolved Issue. Nutrients 2019, 11, 642. [CrossRef] [PubMed]

242. Pittas, A.G.; Jorde, R.; Kawahara, T.; Dawson-Hughes, B. Vitamin D Supplementation for Prevention of Type 2 Diabetes Mellitus: To D or Not to D? J. Clin. Endocrinol. Metab. 2020, 105. [CrossRef]

243. Mostafa, W.Z.; Hegazy, R.A. Vitamin D and the skin: Focus on a complex relationship: A review. J. Adv. Res. 2015, 6, 793-804. [CrossRef]

244. Gabaj, N.N.; Unic, A.; Miler, M.; Pavicic, T.; Culej, J.; Bolanca, I.; Mahecic, D.H.; Kopcinovic, L.M.; Vrtaric, A. In sickness and in health: Pivotal role of vitamin d. Biochem. Med. 2020, 30, 020501.

245. Colotta, F.; Jansson, B.; Bonelli, F. Modulation of inflammatory and immune responses by vitamin D. J. Autoimmun. 2017, 85, 78-97. [CrossRef] [PubMed]

246. Szymczak-Pajor, I.; Drzewoski, J.; Sliwinska, A. The Molecular Mechanisms by Which Vitamin D Prevents Insulin Resistance and Associated Disorders. Int. J. Mol. Sci. 2020, 21, 6644. [CrossRef]

247. Wenclewska, S.; Szymczak-Pajor, I.; Drzewoski, J.; Bunk, M.; Sliwinska, A. Vitamin D Supplementation Reduces Both Oxidative DNA Damage and Insulin Resistance in the Elderly with Metabolic Disorders. Int. J. Mol. Sci. 2019, 20, 2891. [CrossRef] [PubMed]

248. Esser, N.; Legrand-Poels, S.; Piette, J.; Scheen, A.J.; Paquot, N. Inflammation as a link between obesity, metabolic syndrome and type 2 diabetes. Diabetes Res. Clin. Pract. 2014, 105, 141-150. [CrossRef]

249. Rafiq, S.; Jeppesen, P.B. Is Hypovitaminosis D Related to Incidence of Type 2 Diabetes and High Fasting Glucose Level in Healthy Subjects: A Systematic Review and Meta-Analysis of Observational Studies. Nutrients 2018, 10, 59. [CrossRef] [PubMed]

250. Liu, E.; Meigs, J.B.; Pittas, A.G.; Economos, C.D.; McKeown, N.M.; Booth, S.L.; Jacques, P.F. Predicted 25-hydroxyvitamin D score and incident type 2 diabetes in the Framingham Offspring Study. Am. J. Clin. Nutr. 2010, 91, 1627-1633. [CrossRef] [PubMed]

251. Park, S.K.; Garland, C.F.; Gorham, E.D.; BuDoff, L.; Barrett-Connor, E. Plasma 25-hydroxyvitamin D concentration and risk of type 2 diabetes and pre-diabetes: 12-year cohort study. PLoS ONE 2018, 13, e0193070. [CrossRef]

252. Lopez-Baena, M.T.; Perez-Roncero, G.R.; Perez-Lopez, F.R.; Mezones-Holguin, E.; Chedraui, P. Vitamin D, menopause, and aging: Quo vadis? Climacteric 2020, 23, 123-129. [CrossRef] [PubMed]

253. Pittas, A.G.; Lau, J.; Hu, F.B.; Dawson-Hughes, B. The role of vitamin D and calcium in type 2 diabetes. A systematic review and meta-analysis. J. Clin. Endocrinol. Metab. 2007, 92, 2017-2029. [CrossRef]

254. Qu, G.B.; Wang, L.L.; Tang, X.; Wu, W.; Sun, Y.H. The association between vitamin D level and diabetic peripheral neuropathy in patients with type 2 diabetes mellitus: An update systematic review and meta-analysis. J. Clin. Transl. Endocrinol. 2017, 9, 25-31. [CrossRef]

255. Grimnes, G.; Emaus, N.; Joakimsen, R.M.; Figenschau, Y.; Jenssen, T.; Njolstad, I.; Schirmer, H.; Jorde, R. Baseline serum 25-hydroxyvitamin D concentrations in the Tromso Study 1994-95 and risk of developing type 2 diabetes mellitus during 11 years of follow-up. Diabet. Med. 2010, 27, 1107-1115. [CrossRef]

256. Afzal, S.; Bojesen, S.E.; Nordestgaard, B.G. Low 25-hydroxyvitamin D and risk of type 2 diabetes: A prospective cohort study and metaanalysis. Clin. Chem. 2013, 59, 381-391. [CrossRef]

257. Song, Y.; Wang, L.; Pittas, A.G.; Del Gobbo, L.C.; Zhang, C.; Manson, J.E.; Hu, F.B. Blood 25-hydroxy vitamin D levels and incident type 2 diabetes: A meta-analysis of prospective studies. Diabetes Care 2013, 36, 1422-1428. [CrossRef]

258. Li, X.; Liu, Y.; Zheng, Y.; Wang, P.; Zhang, Y. The Effect of Vitamin D Supplementation on Glycemic Control in Type 2 Diabetes Patients: A Systematic Review and Meta-Analysis. Nutrients 2018, 10, 375. [CrossRef]

259. Yousefi, E.; Djalali, M.; Koohdani, F.; Saboor-Yaraghi, S.; Eshraghian, M.R.; Javanbakht, M.H. The effects of vitamin d supplementation on glucose control and insulin resistance in patients with diabetes type 2: A randomized clinical trial study. Iran. J. Public Health 2014, 43, 1651-1656.

260. Maretzke, F.; Bechthold, A.; Egert, S.; Ernst, J.B.; Melo van Lent, D.; Pilz, S.; Reichrath, J.; Stangl, G.I.; Stehle, P.; Volkert, D.; et al. Role of Vitamin D in Preventing and Treating Selected Extraskeletal Diseases-An Umbrella Review. Nutrients 2020, 12, 969. [CrossRef] [PubMed]

261. Pilz, S.; Zittermann, A.; Trummer, C.; Theiler-Schwetz, V.; Lerchbaum, E.; Keppel, M.H.; Grubler, M.R.; Marz, W.; Pandis, M. Vitamin D testing and treatment: A narrative review of current evidence. Endocr Connect. 2019, 8, R27-R43. [CrossRef] [PubMed]

262. Mirhosseini, N.; Vatanparast, H.; Mazidi, M.; Kimball, S.M. The Effect of Improved Serum 25-Hydroxyvitamin D Status on Glycemic Control in Diabetic Patients: A Meta-Analysis. J. Clin. Endocrinol. Metab. 2017, 102, 3097-3110. [CrossRef]

263. Karonova, T.; Stepanova, A.; Bystrova, A.; Jude, E.B. High-Dose Vitamin D Supplementation Improves Microcirculation and Reduces Inflammation in Diabetic Neuropathy Patients. Nutrients 2020, 12, 2518. [CrossRef] [PubMed]

264. George, P.S.; Pearson, E.R.; Witham, M.D. Effect of vitamin D supplementation on glycaemic control and insulin resistance: A systematic review and meta-analysis. Diabet. Med. 2012, 29, 142. [CrossRef]

265. Mitri, J.; Muraru, M.D.; Pittas, A.G. Vitamin D and type 2 diabetes: A systematic review. Eur. J. Clin. Nutr. 2011, 65, 1005-1015. [CrossRef]

266. Moreira-Lucas, T.S.; Duncan, A.M.; Rabasa-Lhoret, R.; Vieth, R.; Gibbs, A.L.; Badawi, A.; Wolever, T.M. Effect of vitamin D supplementation on oral glucose tolerance in individuals with low vitamin D status and increased risk for developing type 2 diabetes (EVIDENCE): A double-blind, randomized, placebo-controlled clinical trial. Diabetes Obes. Metab. 2017, 19, 133-141. [CrossRef] [PubMed] 
267. Wagner, H.; Alvarsson, M.; Mannheimer, B.; Degerblad, M.; Ostenson, C.G. No Effect of High-Dose Vitamin D Treatment on beta-Cell Function, Insulin Sensitivity, or Glucose Homeostasis in Subjects with Abnormal Glucose Tolerance: A Randomized Clinical Trial. Diabetes Care 2016, 39, 345-352. [CrossRef] [PubMed]

268. Marcinowska-Suchowierska, E.; Kupisz-Urbanska, M.; Lukaszkiewicz, J.; Pludowski, P.; Jones, G. Vitamin D Toxicity-A Clinical Perspective. Front. Endocrinol. (Lausanne) 2018, 9, 550. [CrossRef] [PubMed]

269. Tebben, P.J.; Singh, R.J.; Kumar, R. Vitamin D-Mediated Hypercalcemia: Mechanisms, Diagnosis, and Treatment. Endocr. Rev. 2016, 37, 521-547. [CrossRef] [PubMed] 